\title{
A Comprehensive Analysis of European Banking Soundness - Theoretical Study
}

http://doi.org/10.21272/fmir.3(2).17-43.2019

\section{Nahidah Naser}

Cracow University of Economics, Inter-Faculty PhD Studies in English, Poland

\begin{abstract}
This research offers a comprehensive examination of bank soundness using qualitative and quantitative analyses, such as Moody's rating systems, CAMELS or CAMEL, Z-Score, profitability and others relying on available empirical studies, rating outlooks and reports. An extensive assessment of collected data resulted in detailed analysis of quantitative methodologies as well as the examination of the effectiveness of selected macroeconomic determinants to avoid the financial instability. It was noted that the Moody's structure for forecasting banks' failures and credit profiles accurately employed the macro profile qualitative approach. When external factors were added to the Z-score and CAMEL methodologies, the bank soundness predictions were generally improved, even though the change was deemed insignificant in some studies. The direct impact on European banks soundness caused by supervision regulations and regulatory bodies was also investigated. It is noted that the new regulatory measures call for new or adjusted calculations, which led to new requirements on data mining, data analysis, linking of data and quality of data. These new requirements will require IT-implementation and testing, of data aggregation and reporting, development of internal models and risk management improvement to reflect less risk-sensitive regulatory approaches. A comprehensive dynamic model represents the structure of soundness of banks for the selected methodologies, and all possible factors and sub-factors that influence the soundness banks from the qualitative analysis point view.
\end{abstract}

Keywords: Bank profitability; Soundness of banks, Inflation, CAMEL, Z-Score, Moody's Rating, Basel III.

JEL Classification: G21, G24, G01, E40.

(C) The Authors, 2019. This article is published with open access at Sumy State University.

Cite as: Naser, N. (2019). A Comprehensive Analysis of European Banking Soundness - Theoretical Study. Financial Markets, Institutions and Risks, 3(2), 17-43. http://doi.org/10.21272/fmir.3(2).1743.2019 .

\section{Introduction}

The purpose of this review of methodologies is to gain insight into the validity of these methodologies to assess banks soundness and stability. These methodologies are considered as the most repeated methodologies found in empirical studies. Moreover, there are new regulations that have reshaped the structure of soundness of banks, thus new approaches or methodologies are needed in this regard. European banks soundness and profitability is a two-sided coin, in spite of the interdependence and the complex interactions among predicted and unpredicted factors of the financial banking system and with the real economy. Accurate determination of the bank's soundness relies on the profitability of banks while emphasizing the role of macroeconomic determinants is complicated by the time and cross-border dimensions of such interactions. Soundness of banks is difficult to define and even more complicated to measure, since the soundness of European banks and their profitability are intertwined to withstand negative shocks and contribute to the stability of the financial system. There is a lack of comprehensive investigation into the most significant and repeated methodologies for the examination of banks soundness. Therefore, this paper emphasizes the importance of macroeconomic conditions in the different methodologies used to examine the soundness of European banks. It was noted that the Moody's structure for forecasting banks' failures and credit profiles accurately employed the macro profile qualitative approach. 


\section{Objectives of the Study}

The general objective of the theoretical study is to evaluate the most repeated methodologies to examine the soundness of banks.

1. Examine the similarities and differences between the most repeated methodologies to examine the soundness of European banks and profitability.

2. Is there a methodology that depicts the linkages between profitability, market structure, performance and the soundness of banks?

3. Are new regulations, methodologies or supervisory measurements needed to determine European Banks soundness?

\section{Soundness of European banks Methodologies}

This paper brings together the most significant methodologies used to assess the soundness of European banks which are divided into two approaches. The first approach relies on qualitative analysis such as rating systems that are based on financial ratios measurement. The most significant first rating systems are Standard and Poor's Rating Services (1860); Moody's Investors Service Inc. (1909); Thompson Bank Watch (later Fitch Ratings Ltd. in 2000); A.M. Best Company (1899); DBRS(Dominion Bond Rating Service) (1976); Japan Credit Rating Agency (JCR), (1985); Rating and Investment Information, (1998); Canadian Bond Rating Service ( (1972); Duff and Phelps Credit Rating Service (1932); Japanese Bond Rating Institute (1985); Nippon Investor Service (1985) among others. The importance of the rating systems methodology comes from predicting the likelihood of bank failure while considering its' creditworthiness and profitability. A thorough examination of the most frequently used tools to determine bank soundness, such as methodologies, ratings, financial reports and financial outlooks will follow. This paper focuses mainly on the Moody's rating system as a quantitative analysis to evaluate the bank soundness. However, I will introduce only the most significant components regarding this methodology that rely on any new ratings or are related to existing ratings.

A new rating assesses a bank's financial history, strategy and the financial model for evaluating the credit profile. A change in the bank's financial ratios or one of its principal components may lead to reconsideration of its Baseline Credit Assessment (BCA) [1] without re-assessment of its macro profile. However, changes in the given macro profile may not lead to a review of the bank's rating. Any changes in a bank's liability structure may result in an assessment of the LGF component [2] without necessarily reconsidering other components and any changes in the view of government support may lead to a review of the ratings without necessarily reconsidering previous BCA and Preliminary Rating Assessments (PRAs) assessments. The Moody rating system seeks to include all material credit risks into their ratings for both long-term and short-term risks, with the most forward-looking view into these risks.

Specifically, the time frame used in the BCA score cards is a key factor of bank soundness. The bank's problem loan ratio and the bank's profitability ratio focused on the weaker of the three-year average and the latest annual or 12-month period. Also, the annual or 12-month period for the capital ratio, the latest fiscal year-end for funding structure and the liquid asset ratios are examined in both historical and expected contexts with respect to financial performance for periods of several years or more.

\section{Any Baseline Credit Assessment focuses on the following factor}

- Macro Profile. Moody's analysis covers the system-wide factors for forecasting a bank's failure and credit profile. This methodology has been the focus of many academic studies. Moreover, Moody's analysis has been used in other methodologies related to assessing the soundness of banks. It has served as a very reliable source to give insight on the current state of the banking sector by evaluating the macro variables that are significantly affected the soundness of banks, such as:

1. Macroeconomic determinants, e.g. GDP growth and real interest rates;

2. External sector, including capital flows, reserves and the exchange rate;

3. Credit variables, particularly private-sector credit relative to GDP and its growth rate; 
4. Asset prices associated with real-estate values.

The macro profile could include other factors, such as banking country risk and country's propensity of a future risk event.
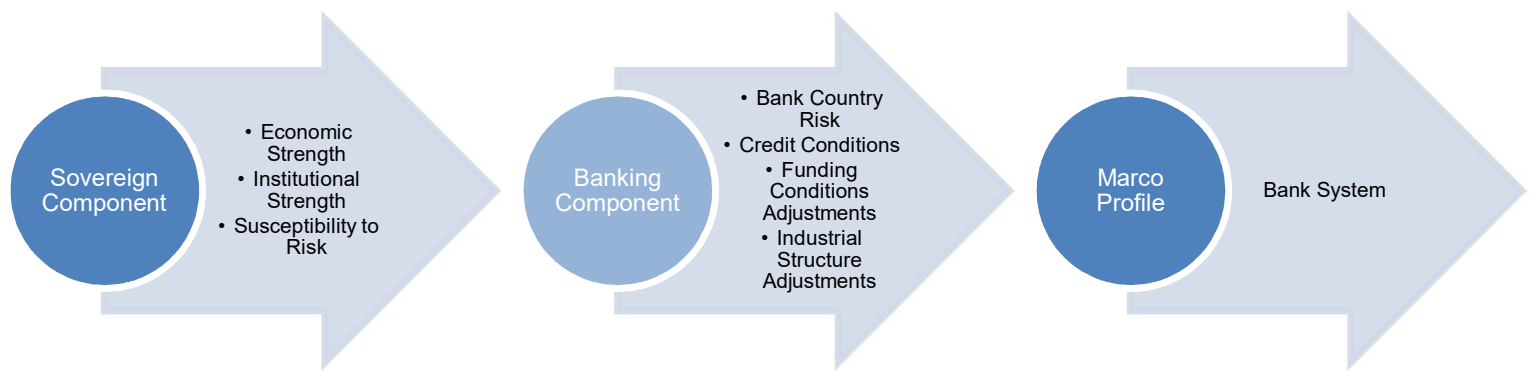

Figure 1. Construct of the Macro Profile, Source: Moody's Investors Service

Source: https://www.moodys.com/researchdocumentcontentpage.aspx?docid=PBC_79004.

The Macro Profile focuses heavily on estimating the sovereign score while taking into consideration the economic strength score for each country.

- Institutional Strength. Moody's methodology relies on several sub-factors for sovereign risk evaluation, so that the strength of the banking system is not a self-referential determinant of its own strength. The strength of a country's institutions is influenced by the effectiveness of its legal framework, such as the inability to enforce contracts and the prevalence of corruption or other general institutional weaknesses, which undermine the relationships between lenders and creditors, resulting in a weaker banking system.

- Financial Ratios. Moody's financial ratios are comprised of the macro and financial profiles (bankspecific characteristics). Moody's approach determines a bank's intrinsic resistance to failure, financial strength and bank's credit strength. Therefore, solvency represents the combination of asset risk, leverage and earnings unpredictable quality asset requires higher capital and/or returns while liquidity is determined by a bank's funding profile together with its ability to access cash (unreliable bank's sources of funding require a buffer of liquid assets). Moreover, these factors are equally important, since strongly capitalized banks are more likely to absorb losses, attract counterparties and minimize liquidity risk problems. Greater liquid assets indirectly enhance solvency because they imply that a bank is less likely to sell illiquid assets at a loss in the event of a funding problem. The reverse scenario is also true as weak solvency can undermine liquidity.

The core characteristics of bank's financial profile are solvency and liquidity. For solvency, gross risk defines the risk of a loss of value in the bank's assets, and liquidity defines the risk of a loss of funding. Potential mitigants include capital and profit generation for solvency, and access to cash and liquid asset reserves, including routine central bank facilities for liquidity. The five fundamental credit sub-factors are as shown in Table 1:

Table 1. Schematic of Financial Profile [4]

\begin{tabular}{|l|l|l|l|}
\hline \multicolumn{2}{|l|}{ Financial Profile } \\
\hline Solvency Total Weight 65\% & Liquidity Total Weight 35\% \\
\hline Asset Risks & Capital Weight 25\% & Funding Structure & Liquid Resources \\
\cline { 2 - 3 } Weight 25\% & Profitability Weight $15 \%$ & Weight 20\% & Weight $15 \%$ \\
\hline
\end{tabular}

Source: Moody's Investors Service.

\section{Qualitative Factors}

This paper agrees with Moody's methodology that there are other unmeasured predictive factors that play significant roles in influencing the resilience of banking sector. For example, the strength and reliability of a country's institutions; the ability to retain law and order and avoid corruption; the presence or absence of system-wide liquidity mechanisms or funding vulnerabilities, and structural advantages or deficiencies to analyse sovereign creditworthiness. The factors behind banking crises are thus closely linked to but are not exclusive to sovereign and currency crises. When credit metrics are 
used to evaluate the historical performance, the outlook trends and qualitative adjustments to the ratiodriven score are important qualitative contributors to the soundness of a financial institution. Three key factors are as follows: business diversification, opacity / complexity and corporate behavior. Adjustments with respect to business diversification and corporate behavior can be either positive or negative; while opacity / complexity are negative only.

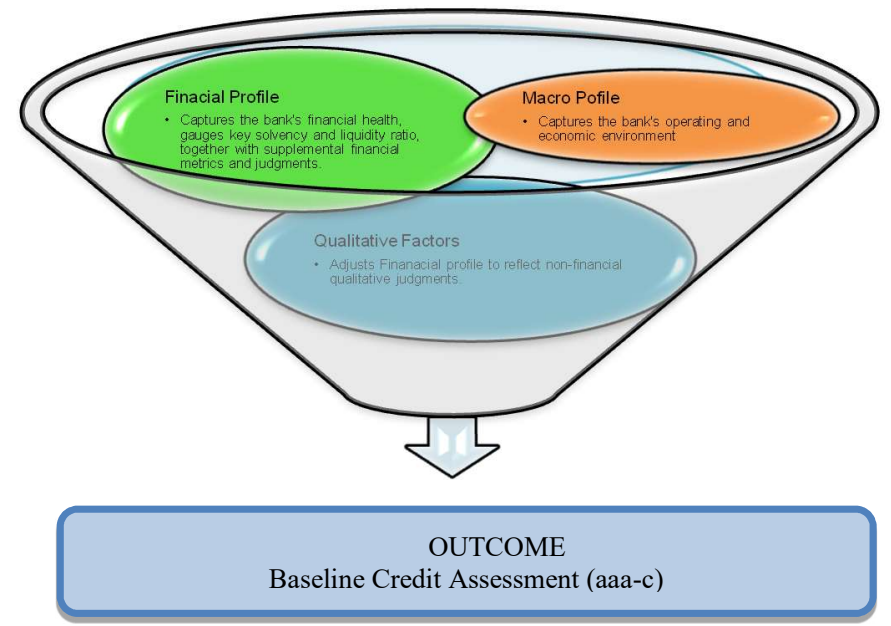

Figure 2. BCA Structure, Source: Moody's Investors Service

Table 2. A summary of Moody's Rating Outlooks for some of European Banks

\begin{tabular}{|c|c|}
\hline Country & The Outlook According to Moody's Rating System \\
\hline Germany [5] & $\begin{array}{l}\text { The German banks are rated as stable with strong capital and high loan quality. These factors provide a cushion against } \\
\text { rising profitability pressures due to persistently low interest rates. The German GDP growth was } 2.2 \% \text { in } 2018 \text { and } 1.7 \% \\
\text { in } 2019 \text {. The German economy is driven by rising domestic demand, while the unemployment continues to remain low. } \\
\text { Borrowers' debt repayment capacity stays high due to low levels of corporate and household indebtedness. } \\
\text { German banks are in compliance with minimum capital requirements, liquidity and bail-in-able liabilities. German banks } \\
\text { are well-positioned to deal with their chronically weak profitability due to minimal amounts of problem loans and loss } \\
\text { provisioning needs. At the end of } 2017 \text {, the non-performing loans (NPLs) were } 2.5 \% \text { of gross loans. The sound perfor- } \\
\text { mance of domestic retail and corporate loans during } 2018 \text { and through } 2019 \text {, are driven by stable employment rate and } \\
\text { positive economic growth. The higher risk to German lenders comes from foreign loans and securities, which represent } \\
\text { a quarter of German banks' total assets. } \\
\text { Low interest rates counteract the main banks' income source, net interest margins. The low levels of loan loss provision- } \\
\text { ing have left small window for any declines in pre-provision income to be improved in } 2018 \text { and through } 2019 \text {. By } \\
\text { maintaining the } 2018 \text { economic growth momentum into } 2019 \text {, the German Banks are likely to moderately grow their } \\
\text { balance sheets. The ratios of tangible common equity (TCE) ratios of German banks remain stable. }\end{array}$ \\
\hline Austria [6] & $\begin{array}{l}\text { The Austrian banking system changed from positive to stable due to moderate improvements in loan quality and slow } \\
\text { capital generation. The strength of the Austrian economy was demonstrated by the } 3 \% \text { growth in } 2018 \text { with a further } \\
2.5 \% \text { forecasted growth for } 2019 \text {. This environment boosts banks' credit fundamentals and strengthens their resilience } \\
\text { against economic shocks. There was improvement in loan performance but in a slower pace than desired, so its positive } \\
\text { impact on banks' earnings will be dampened. } \\
\text { The loan quality problem declined from } 5.6 \% \text { in } 2016,4.4 \% \text { in } 2017 \text { and will be around } 4 \% \text { by end of } 2019 \text {. Capital } \\
\text { levels of Austrian banks will steadily improve, reflecting the balance between strong income generation, rising loans and } \\
\text { more generous dividend pay-outs. The Tier } 1 \text { ratio is expected to be around } 3 \% \text { by the end of } 2019 \text { while it was } 14.9 \% \\
\text { in } 2017 \text { and } 14.5 \% \text { in } 2016 \text {, respectively. Profitability of Austrian banks was supported by low credit provision in } 2018 \\
\text { and will continue in } 2019 \text {. Austrian Banks cost to income rates will remain stable as efficiency improvements will only } \\
\text { have an impact on earnings over the medium term. }\end{array}$ \\
\hline France [7] & $\begin{array}{l}\text { The French banking system remains stable as economic growth encourages the availability of bank credit services and } \\
\text { supports borrowers to service their debts. Additionally, the French banks diversified revenue serve to boost profitability } \\
\text { despite pressure on interest income from low interest rates. The French GDP was } 1.7 \% \text { in } 2018 \text { and is expected to be } \\
\text { around } 1.6 \% \text { in } 2019 \text {. The private-sector debt rose due to a low interest rate environment, the risks of higher debt levels } \\
\text { were evened out by the improved performance of French corporations and a healthy home-loan market. } \\
\text { A favourable economic environment enhances the capacity of borrowers to repay debts, with the lowest loan-loss provi- } \\
\text { sioning since } 2012 \text {. For the five largest French banks, loan-loss provisioning charges declined by } 21 \text { basis points (bps) of } \\
\text { outstanding loans due to better asset quality in non-domestic retail markets. The well diversified income resources en- } \\
\text { courage broadly stable profitability as insurance and asset management put an ease on interest margins in retail banking. } \\
\text { However, French banks forecast higher operating costs and the average cost-to-income ratio of around } 68 \% \text {. }\end{array}$ \\
\hline Spain $[8]$ & $\begin{array}{l}\text { The Spanish banking system is stable thanks to the improvement of asset quality, robust economic growth and disposal } \\
\text { of troubled assets. Most of the fundamental factors, such as capital, funding and liquidity levels and profitability are } \\
\text { stable. Stocks of non-performing loans improved against } 2014 \text { records and will continue to improve. Solid economic } \\
\text { growth is backing a stable operating environment. While Moody's expects growth to slow } 2.3 \% \text { in } 2019 \text { against } 2.7 \% \text { in }\end{array}$ \\
\hline
\end{tabular}




\begin{tabular}{|c|c|}
\hline & $\begin{array}{l}\text { 2018, Spain's economy is still among the fastest growing in the euro area. This robust economic growth reflects lower } \\
\text { unemployment rates and improvement in credit conditions for Spanish banks. } \\
\text { The low quality of capital in Spanish banks undermines the capital's strength. However, the capital will continue to be } \\
\text { stable at low levels due to their large volume of deferred tax assets. A broadly stable profitability has been forecasted for } \\
2019 \text {. Higher fee and commission income will cover the declined net interest income, as revenues will benefit from more } \\
\text { diverse earning sources and the cost of risk is expected to remain broadly stable. There is stable funding and liquidity } \\
\text { conditions over the outlook period. In the past few years, the funding gap has narrowed due to stable deposits and shrinking } \\
\text { loan books at Spanish banks. This process will decelerate when demand rises for credits. }\end{array}$ \\
\hline UK [9] & $\begin{array}{l}\text { The UK banking sector remains stable with strong capital, better profitability and strong liquidity to bolster the operating } \\
\text { conditions and asset quality over next year. The UK and the European Union (EU, Aaa stable) will agree on a transition } \\
\text { period after the UK's planned departure has shifted to } 31 \text { October } 2019 \text { with further uncertainty on the final date. However, } \\
\text { operating conditions for banks are hindered by the uncertainties surrounding the Brexit. This has resulted in slow eco- } \\
\text { nomic growth and lower interest rates to increase competition. The economy experienced a moderate downturn in asset } \\
\text { quality. However, the strong solvency and high quality of capital in UK banks will cover any unexpected losses. } \\
\text { For large UK banks, a decline in costs due to lower conduct and litigation expenses will counterbalance revenue pressures } \\
\text { from low interest rates, supporting their profitability. A moderate decline of operating and restructuring costs will com- } \\
\text { pensate for a small increase in credit costs. Thereby, maintaining a strong level of funding profiles and low loan-to- } \\
\text { deposit ratios, and lengthening wholesale debt maturities. The large UK banks will promote strong liquidity via regulatory } \\
\text { requirements while they try to amass buffers ahead of Brexit. }\end{array}$ \\
\hline Polan & $\begin{array}{l}\text { The Polish banking system is stable, as a strong economy provides assistance to the banking sector and boosts the banks' } \\
\text { loan quality. The strong economic growth can be seen as } 5 \% \text { in } 2018 \text { and around } 4.2 \% \text { is expected in } 2019 \text {, while the } \\
\text { European Union average of } 2.7 \% \text { due to domestic demand and the inflow of EU funds, which equated to } 23 \% \text { of nominal } \\
\text { GDP last year. Modest improvement in Banks' loan performance caused by high level of employment rates, domestic } \\
\text { consumption as well as strong investment. The capital of Poland's banks stays strong with support of balanced loan } \\
\text { growth and stronger earnings with moderated dividend payments. } \\
\text { Sound profitability caused by high interest rates across Europe. Banks' efforts to provide loans for small- and medium- } \\
\text { sized enterprises, and consumers. Provisioning cost remains and continues at a low level due to the favourable economic } \\
\text { environment. Polish banks have limited reliance on wholesale markets, the market funding rises modestly due to increas- } \\
\text { ing the use of covered bonds in banks; while a funding source provides a stable base for growth. Polish banks issue bail- } \\
\text { in debt to meet minimum requirements for own funds and eligible liabilities (MREL) by end of } 2019 \text {. The above stated } \\
\text { factors reflect positively and significantly on banks regardless of ongoing conflict with the European Union and policy } \\
\text { uncertainties. }\end{array}$ \\
\hline Czech [11] & $\begin{array}{l}\text { The Czech Republic's banking system has been upgraded from stable to positive with anticipation to upgrade further due } \\
\text { to improvements in banks' credit profiles over the next year. Strong GDP figures were achieved in } 2017 \text { of } 4.3 \% \text { and } \\
\text { again in } 2018 \text { of } 3.3 \% \text { with } 3.0 \% \text { growth expected in } 2019 \text {. The growth comes from strong private consumption, invest- } \\
\text { ment and European Union funding. Strong economic growth and low employment rates reflect a healthy credit level and } \\
\text { steady debt repayments. Friendly economic conditions will benefit loan performance despite mild pressure due to sea- } \\
\text { sonable loan portfolios. } \\
\text { The Czech banks' problem loans are the lowest among Central and Eastern Europe (CEE), the non-performing loans } \\
\text { averaging } 2.5 \% \text { in } 2017 \text { and } 2.3 \% \text { mid } 2018 \text {, and the largest banks have solid levels of loan-loss reserves around } 80 \% \\
\text { according to Moody's-rated banks. The capital of Czech banks is considered as stable with an average of Common Equity } \\
\text { Tier } 1 \text { capital ratio of } 18.14 \% \text { at the end of } 2017 \text {. However, a capital decline may occur if banks increase their dividend } \\
\text { pay-outs. A stable increase in interest rates as well as strong lending growth will benefit Czech banks revenues in } 2019 \text {. } \\
\text { Higher profitability is expected due to higher-yielding small-business and consumer loans. However, higher risks, nor- } \\
\text { malising credit costs and higher operating expenses due to strong wage growth for CEE region may temper this rise. }\end{array}$ \\
\hline B & $\begin{array}{l}\text { The latest Moody's outlook regarding Bulgarian banks stated that high profit gains, high capital buffers and stable funding } \\
\text { boost the outlook. However, asset risk, stemming primarily from corporate lending remains high with slow non-perform- } \\
\text { ing loans resolution processes. Both interest and non-interest income will be supported by increased business opportuni- } \\
\text { ties and credit growth. Bulgarian banks' net profit was } 41 \% \text { in } 2016 \text {, equivalent to a return on equity of } 10.4 \% \text { with lower } \\
\text { loan-loss provisions and tough cost control supported earnings growth and organic capital generation. Aggregate Com- } \\
\text { mon Equity Tier } 1 \text { and total capital ratios were at } 20.4 \% \text { and } 22.2 \% \text {, respectively. } \\
\text { Stable funding and high liquidity had a positive effect on banks' profitability, since the Bulgarian banks were deposit } \\
\text { funded. By the end of } 2016 \text {, deposits were } 79 \% \text { of total assets, excluding general government and credit institutions, while } \\
\text { the loans to deposits ratio improved to } 75 \% \text { against } 101 \% \text { at the end of } 2012 \text {. Moody's upgraded the Bulgarian Banks' } \\
\text { Deposit Ratings [13] to Baa3/Prime-3 for the long and short-term local and foreign-currency deposit ratings of Raiffeisen } \\
\text { bank (Bulgaria) and to Ba3 for the long-term. Prior to the financial crisis, higher levels of asset risk and indebtedness } \\
\text { were associated with the corporate sector, and it was beyond banks' ability to restrain the profitability and investment } \\
\text { without being at risk of bankruptcies. Resolving non-performing exposures (NPEs) remains largely unmanageable while } \\
\text { problems with new loans have declined. NPEs declined to } 18.5 \% \text { of gross loans in } 2016 \text { from } 20.6 \% \text { in } 2015 \text { according } \\
\text { to the Bulgarian National Bank's broad while loans stood at } 13.0 \% \text { of gross loans as of December } 2016 \text {. }\end{array}$ \\
\hline $\begin{array}{l}\text { Netherlan } \\
{[14]}\end{array}$ & $\begin{array}{l}\text { Strong domestic economy growth supports the Dutch banking system and the performance of banks' assets. A slight } \\
\text { decline is expected in GDP growth from } 3 \% \text { in } 2018 \text { to } 2.5 \% \text { in } 2019 \text {, then to } 2.1 \% \text { percent in } 2020 \text {. Several key factors, } \\
\text { such as a strong, albeit softening, housing market, tax cuts and low unemployment rates will support private consumption } \\
\text { and investments will continue to support economic growth. The Dutch economy keeps performing slightly better than } \\
\text { the average European economy, providing a strong background for domestic banks. Strong banks' asset quality is due to } \\
\text { good performance of the domestic loan exposures. } \\
\text { Over fifty percent of Dutch banks' loan exposures are related to the domestic economy. However, a moderate increase in } \\
\text { loan-loss charges is expected during } 2019 \text { due to substantial releases of impairment provisions in } 2017 \text { and } 2018 \text {. Dutch } \\
\text { banks face the biggest increase in capital requirements under Basel III, as their capital models currently result in low risk } \\
\text { weights since Dutch banks are among those best capitalised on a risk-weighted basis. Dutch banks' profitability will be } \\
\text { lower as interest rates remain low, and as a result there will be higher loan-loss charges. Some of the negative pressure } \\
\text { on profit margins will be offset by minimizing banks' operating costs. }\end{array}$ \\
\hline
\end{tabular}




\begin{tabular}{|c|c|}
\hline Greece [15] & $\begin{array}{l}\text { By improving the banks' funds and asset risks in 2019, the Greek banking system will be positive due to tough operating } \\
\text { environment. Moody's expects that the Greek economy will continue to improve by encouraging foreign investment via } \\
\text { the government's structural reforms. The Greek GDP had growth of } 2 \% \text { in } 2018 \text { with } 2.2 \% \text { expected in } 2019 \text { due to a } \\
\text { strong increase in exports, tourism and other services. Moody [16] upgraded the long-term deposit ratings of Piraeus } \\
\text { Bank S.A. and National Bank of Greece S.A. to Caa2, and Caa3 for long-term deposit for all Alpha Bank AE, Eurobank } \\
\text { Ergasias S.A. and Attica Bank. Greek problem loans are gradually decreasing due to the strict loan recovery laws. } \\
\text { Non-performing exposures (NPEs) are expected to be around 35\% of gross loans by the end of } 2019 \text {, meaning that banks } \\
\text { could meet their obligations. The quality of Greek bank capital was weakened by Deferred Tax Assets (DTAs); however, } \\
\text { they are floating at comfortable levels, with a common equity Tier } 1 \text { (CET1) ratio around } 15.8 \% \text { at the beginning of } 2018 \text {. } \\
\text { Greek banks were less reliant on central bank funding and emergency liquidity assistance (ELA). By regaining access to } \\
\text { the interbank and deposits, banks were more likely to end ELA's assistance at the beginning of } 2019 \text {. Most Greek banks } \\
\text { will stay slightly profitable through } 2019 \text {. However, net interest margins will remain pressured as banks continue to } \\
\text { reduce their leverage ratios and loan balances by write-offs and sales of NPEs. }\end{array}$ \\
\hline Italy [17] & $\begin{array}{l}\text { The persistent negative outlook for the Italian banking system is due to higher funding costs and potential tax increases, } \\
\text { which outweigh the positive impact of solving problem loans. On October 23, 2018, Moody's [18] downgraded the rating } \\
\text { of } 12 \text { Italian financial institutions, the long-term deposit ratings and/or the Counterparty Risk Ratings (CRRs) of eight } \\
\text { banks, the long-term issuer and/or senior unsecured debt ratings of three institutions, and the long-term Counterparty Risk } \\
\text { Assessments (CRAs) of seven banks. Furthermore, Moody's graded the standalone baseline credit assessments (BCAs) } \\
\text { of Banca IMI S.p.A. (Banca IMI) at baa3 and of Credit Agricole Cariparma S.p.A. (CA Cariparma) at ba1. } \\
\text { Italian banks have to repay the cheap funding drawn under the European Central Bank's Targeted Long-Term Refinancing } \\
\text { Operations (TLTROs) in 2020-2021. Additionally, Italian banks are required to hold more bail-in-able debt, raise retail } \\
\text { bonds and additional deposits, thus increasing Italian lenders' reliance on more expensive market funding. Italian banks' } \\
\text { profitability will be counteracted due to more expensive funding caused by higher government bonds and cost of bank } \\
\text { debt. Additionally, tax proposals in Italy's } 2019 \text { budget law could burden banks' earnings. The economic conditions in } \\
\text { Italy are moderately stable with real GDP growth of } 1 \% \text { in } 2018 \text { and } 1.3 \% \text { in } 2019 \text {, supporting improving credit quality. } \\
\text { Moody's forecasts Italian banks' problem loan ratio to fall further in } 2019 \text { from } 11 \% \text { at the end- } 2018 \text { and } 14.5 \% \text { a year } \\
\text { earlier. }\end{array}$ \\
\hline Irela & $\begin{array}{l}\text { The Irish banking system had a boost upgrade from Moody's rating by the end of } 2018 \text { due to improvement in asset } \\
\text { quality as the economy continues to grow; banks restructure reforms and the disposal of problem loans. After real GDP } \\
\text { grew by } 7.2 \% \text { in } 2017 \text {, a moderate expansion of } 5.0 \% \text { and } 3.5 \% \text { in } 2018 \text { and } 2019 \text { respectively were experienced. Ireland's } \\
\text { economic growth is due to higher increase in exports and productivity gains, as well as the presence of large and growing } \\
\text { multinational corporations. The impact of Brexit (Aa2 stable) creates uncertainty; however, the impact on Irish banks is } \\
\text { expected to be contained. Asset quality is to be improved as solid GDP growth supports borrowers' finances, while banks } \\
\text { continue to sell and restructure problem loans. } \\
\text { The European Central Bank urges EU banks to cut their ratio of non-performing exposures to total exposures to normalised } \\
\text { levels over the medium term. The Irish banking system's NPE ratio was } 13.9 \% \text { in } 2018 \text {. Irish banks will continue to } \\
\text { manage their solvency ratios through strong internal capital generation and low risk-weighted assets during } 2018 \text { with a } \\
\text { broadly stable profitability. The effective countercyclical capital buffer in July } 2019 \text { ensures that banks will preserve their } \\
\text { currently strong capital bases amid strong economic growth; a resurgent property market and sufficiently solid banks' } \\
\text { liquidity position to refinance risk. The largest three Irish banks will have better chances with government support for } \\
\text { the deposits and senior unsecured debt. However, other banks will have less probability of government support based on } \\
\text { their creditworthiness' prediction over the next year. }\end{array}$ \\
\hline & $\begin{array}{l}\text { At the beginning of 2019, Moody's upgraded Bank of Cyprus Public Company Limited's (Bank of Cyprus), Hellenic } \\
\text { Bank Public Company Ltd's (Hellenic Bank) long-term deposit ratings to B3 and the long-term Counterparty Risk Ratings } \\
\text { (CRRs) to B1. Hellenic Bank's baseline credit assessment (BCA) and adjusted BCA upgraded to caa1, and its long-term } \\
\text { Counterparty Risk Assessment (CRA) to B1. These three largest domestically active banks accounted for around } 64 \% \text { of } \\
\text { system assets. The upgrade was due to changes in the banks' liability structure, depositor protection and non-debt coun- } \\
\text { terparty financial liabilities captured by the CRR. } \\
\text { The Cypriot banking system reflects fast-paced economic expansion growth, supporting borrowers' repayment capacity, } \\
\text { asset values and new lending. The real GDP was } 3.5 \% \text { in } 2018 \text { and } 2.8 \% \text { in } 2019 \text {, driven by booming tourism; resilient } \\
\text { domestic consumption and a recovering real-estate market. High private-sector indebtedness hindered growth opportuni- } \\
\text { ties for banks. The Banks continue to restructure their troubled loans, selling off real-estate collateral and reducing non- } \\
\text { performing loans at the three core domestic banks from around } 45 \% \text { in } 2017 \text { to around } 35 \%-38 \% \text { in } 2018 \text {. Banks had } \\
\text { moderate growth in capital buffers, however, vulnerable capital due to the high stock of non-performing loans that were } \\
\text { not covered by cash provisions remained. The provisioning gap was largely covered by real-estate collateral, but any } \\
\text { deterioration in the real-estate market would diminish the banks' ability to recover debts through real-estate sales, so they } \\
\text { would need to set aside extra provisions. The ratio of NPLs to provisions plus capital was around } 120 \% \text { considered to be } \\
\text { one of the lowest in Moody's rating universe. There were modest profits for domestic Cypriot banks in } 2018 \text { due to } \\
\text { lowering the provisioning costs. }\end{array}$ \\
\hline Norway [22] & $\begin{array}{l}\text { The Norwegian banking system was upgraded from negative to stable thanks to their solid operating environment and by } \\
\text { the support of the banks' credit quality } 2019 \text {. The economic environment will be broadly supportive of banking operations } \\
\text { with modest improvements in the risk profile of the banks. The GDP growth was } 1.8 \% \text { in } 2017 \text {, up to } 2.4 \% \text { in } 2018 \text { and } \\
\text { is expected to be } 2.2 \% \text { in } 2019 \text {. The Banks' fundamentals are expected to remain solid as a result of improved loan quality, } \\
\text { resilient profitability and strong capital ratios. } \\
\text { The Norwegian banks face risks from Norwegian households' high indebtedness, at } 224 \% \text { of disposable income due to } \\
\text { low interest rates. At the beginning of } 2019 \text {, the Norway's version of the EU Bank Recovery and Resolution Directive } \\
\text { (BRRD), which will shift the cost of bank failure from taxpayers to creditors will result in lower Moody's government } \\
\text { support assumptions and have a negative effect on their rating. However, the minimum requirements of Norway banks' } \\
\text { funds and eligible liabilities (MREL) rules may counteract this negative pressure. }\end{array}$ \\
\hline
\end{tabular}

In summary, the literature search confirms that the Moody rating outlooks and reports for European banking systems are focused on the macro profiles to grade the banking systems, including determinants such as real GDP, interest rates, Tier 1, non-performing loans and others. Additionally, the history of 
banks' performance and profitability play a significant role in determining and predicting the soundness of banks by including the macro and risk profiles. It should be noted that this paper does not cover every European Banking system instead selected example country, which clearly highlight the most significant macroeconomic variables pertinent to Moody's reports and outlooks. There are many advantages of the Moody's rating as measurement of banks soundness because Moody's analysis uses both quantitative and qualitative factors rather than using only balance sheets variables. Moreover, the Moody's rating reports capture the solvency independent of the safety net. However, the shortcoming lies in the fact that Moody's reports focuses on large banks and neglects the small banks (DemirgucKunt, A., Detragiache, E. and Tressel, T., 2006).

Many methodologies have been introduced to predict banks' financial deterioration. Some methodologies depend on country by country approach for a quick estimation of the soundness of banks relying on assets, liquidity, capital, performance and earnings without always taking in consideration the macro profile. The CAMEL methodology was designed to generate financial soundness ratings and has been recommended by the IMF and the World Bank (2005). The CAMEL methodology consists of five components: Capital adequacy, Asset quality, Management competence, Earnings, and Liquidity. Rich empirical studies have examined the efficacy of CAMEL ratings and reached the conclusion that publicly available data combined with regulatory CAMEL ratings can identify and/or predict banks failure. It is worth mentioning that prior to any crisis and even with strong economic indicators, such as growth economies, low inflation, budget surpluses, low unemployment and declining government foreign debt, many financial institutions were still caught off-guard when the crisis was triggered by imported crises, e.g. the collapse of Lehman Brothers, US subprime crisis and the Asian financial crisis.

For instance, prior to the Asian financial crisis, most Southeast Asian economies were characterised by strong economic indicators such as strong growth, low unemployment and inflation rates, and declining government foreign debt. Nevertheless, in 1997, the crisis was trigged by Thailand's devaluation and the financial markets were caught off guard (Bustamam, U. S. A., 2017; Hays, F. H., De Lurgio, S. A., \& Gilbert, A. H., 2009; Gasbarro, D., Sadguna, I. G. M., \& Zumwalt, J. K., 2002; Miller, M. H., 1998). Adding to that, even with highly supervised and regulated banking sectors, sometimes banks can be taken by surprise due to the influence of macroeconomic profile (such as existence of foreign exchange risks, or other unseen macro profile problems) that jeopardize the financial soundness of banking sectors. For example, the Southeast Asian countries suffered from substantial maturity risk caused by taking short-term debt to finance long-term investments. Moreover, the debt was denominated in U.S. dollars to finance projects in local currency. If the economic conditions are stable, then all CAMEL components are significantly related to the CAMEL ratings. However, as economic conditions deteriorate, CAMEL becomes inadequate as a methodology to reflect bank soundness. Moreover, the management and regulators' priorities are subject to change (Gasbarro, D., Sadguna, I. G. M., \& Zumwalt, J. K., 2002).

The first five traditional CAMEL components measure the financial soundness of banks (Kumar, Mishra Aswini, et al, 2012), such as operating soundness, performance, financial condition and regulatory compliance of the banking organization. The management quality is a measure of the bank's health and stability. The bank performance is considered as a qualitative factor. However, further indicators are used to evaluate the soundness of banks, such as cost to income ratio, management and operating expenses as a percentage of total assets, operating revenue to total profit, deposit interest expense as a percentage of total deposits, non-interest expense to the sum of net interest income and non-interest income, and personnel expenses to average assets. The cost to income ratio measures the capacity of a bank to cover its operating expenses. As far as earnings and profitability of a bank, different indicators are used, such as Return on Assets and Return on Equity. The return on assets determinant underlines how effective the bank assets are at generating revenues. The return on equity must be interpreted with prudence, as a high level can underline a high profitability but also a low level of capitalization, while a low level emphasizes a low level of profitability and a high capitalization of the bank.

Liquidity is the most significant component and has a significant impact on a bank's financial soundness and indicates the capacity of the bank to pay its short-term debts and face unexpected withdrawals of depositors. Many liquidity ratios have been used in previous empirical studies, such as the ratio of total loans to total assets, the ratio of the net loans to total deposits and short-term funding, the ratio of the 
liquid assets to total assets, the ratio of liquid assets to customer and short-term deposits and others (F. Pasiouras, K. Kosmidou, 2007; Marijana Ćurak et al., 2012; Roman, A., \& Şargu, A. C., 2013; Nicolae Petria et al. 2015 and others).

In 1997, the U.S. regulators added a sixth factor "S" designed to capture Systemic risk (CAMELS). This systemic component is used to capture a bank's sensitivity to market factors, such as interest rate, foreign exchange and price risk. The importance of the systemic factor varies over time and across institutions, but is more noticeable during a crisis (Gasbarro, D., Sadguna, I.G.M. and Zumwalt, J.K., 2002; Hays, F. H., De Lurgio, S. A., \& Gilbert, A. H., 2009; Dincer, H., Gencer, G., Orhan, N., \& Sahinbas, K., 2011; Roman, A., \& Şargu, A. C., 2013). Market risks could involve more than one type of risk that will have an instant impact on financial institution's earnings, liabilities, and off-balance sheets. In order to improve the validity of the CAMEL Score, other variables are also considered, such as share of total bank assets held in government-owned banks in each country, share of total bank assets held in foreign-owned banks in each country, concentration, bank size, GDP per capita, average rate of real GDP growth, bank securities, bank insurance, ownership of banks, index of private monitoring of banks by the private marketplace.

CAMEL or CAMELS variables influence the soundness and safety of banks without ignoring the necessity to include bank-specific and macroeconomic determinants to improve the prediction rates. All banks are affected by changes in the macro profile; however, banks have different approaches to address risk-taking preferences and management quality. Therefore, banks react differently to the similar determinants that affect their operations over time (Gasbarro, D., Sadguna, I. G. M., \& Zumwalt, J. K., 2002; Kumar, M. A., Harsha, G. S., Anand, S., \& Dhruva, N. R. 2012; Roman, A., \& Şargu, A. C.,2013; Dang, U., 2011; Baral, K. J., 2005; Kaur, H. V., 2010; Barth, J. R., Dopico, L. G., Nolle, D. E., \& Wilcox, J. A., 2002; Manoj, P. K., 2010; Muhmad, S. N., \& Hashim, H. A., 2015; Ishaq, Abdul, et al, 2016).



Figure 3. Describes the Composite of CAMEL Rating System [23]

A Z-score test (distance to default) is another methodology that mirrors the probability of a financial institution's insolvency, in other words, when the value of bank's assets becomes lower than the value of its debt. It measures the sum of bank's return on assets and equity to assets ratio divided by the standard deviation of return on assets. A higher z-score emphasizes a lower probability of insolvency. Empirical studies such as Boyd and Runkle (1993); Demirguc-Kunt, A., Detragiache, E., \& Tressel, T. (2006); Demirguc-Kunt, A., \& Levine, R. (2008); Demirgüç-Kunt, A., \& Detragiache, M. E. (2010); 
Schaeck, K., \& Čihák, M. (2008); Laeven and Levine (2009); Čihák and Hesse (2010); I Lapteacru (2016); I Lapteacru (2017) among others used the Z-score to determine the bank stability. The Z-score is the proper tool for assessing financial institutions' stability if the financial institutions can smooth out their reported data. However, Z-score looks at each financial institution individually, ignoring the fact that the risk of default in one financial institution may cause losses to other financial institutions. Also, all banks are subject to insolvency risks, even though Z-scores assess the risk of default in different groups of banks, which may be subject to different ownership or objectives.

According to Chiaramonte, L., Liu, H., Poli, F., \& Zhou, M. (2016), Z-score managed to predict 76\% of bank failures, while adding a set of macroeconomic and industrial determinants had insignificantly increased the model's predictability. Second, the short-term, the Z-score forecasting ability had an accuracy of $74 \%$ for bank failures. To our knowledge, the insignificant increase of Z-score comes from data selection and banks' ownership against macroeconomic stability during conducting the test within a three-year period. The macroeconomic determinants have a significant impact on bank risk which proved difficult to predict the impact through a narrow time window. Some studies evaluated the soundness of banks by using a number of internal, bank-specific and macroeconomic variables, such as capital ratio, return on average assets before tax, real interest rates and GDP per capita, inflation and GDP Growth (Chiaramonte, Laura, et al. 2016; Demirgüç-Kunt, A., \& Detragiache, E., 2011; Schaeck, K., \& Čihák, M., 2008; Uhde, A., \& Heimeshoff, U. , 2009; Mirzaei, A., Moore, T., \& Liu, G. 2013; Schaeck, K., \& Cihák, M., 2014).

Mirzaei, A., Moore, T., \& Liu, G. (2013) examined the connection between market structure, profitability and banking soundness using the Z-score. The Z-score was positively and significantly related to the condition in an emerging market and had a positive impact on bank stability. However, a significant negative of the Z-score was shown only in advanced economies, hence concentrated markets pose some risk in matured banks. Their findings suggested that the emerging markets can be more profitable than advanced markets (West European Markets).

The next two papers capture bank soundness through Z-score and adding compliance with BCPs (Basel Core Principles) to the model. The first paper did not support the premise that the better compliance was expected with BCPs [24]. Surprisingly, the empirical results showed that more compliance (BCPs) were associated with riskier banks, since riskier banks had strong incentives to comply with regulations and supervisory requirements. Theoretically, the endogeneity of supervision may bias the relationship with soundness of banks. The BCP compliance index was an insignificant determinant of banking system soundness, but positively related to the Z-score (Demirgüç-Kunt, Asli, and Enrica Detragiache, 2011).

The second paper by Demirguc-Kunt, A., Detragiache, E., \& Tressel, T. (2006) examined the impact of compliance with BCPs on the soundness of banks through Moody's rating and Z-score. Their results showed that there was a positive relationship between compliance with BCPs (specifically, with information provision) whether bank soundness was measured via Moody's ratings or through Z-scores. Moreover, adding factors such as institutional quality, macroeconomic variables, sovereign ratings, the results were robust (even though results were not reported). Their findings emphasized the importance of transparency during supervisory processes and strengthening market discipline. However, during the financial crises, the relationships between financial characteristics and Z-score became ineffective due to the decline of capital adequacy and asset quality's deterioration due to non-performing loans and management quality focused only on short-term survival (see Chen, S., \& Holdings, C. F., 2007; Takang, F. A., \& Ntui, C. T, 2008; Demyanyk, Yuliya, and Iftekhar Hasan, 2010; Agarwal, V., \& Taffler, R., 2008; Sangmi, M. U. D., \& Nazir, T., 2010; Chiaramonte, L., Liu, H., Poli, F., \& Zhou, M., 2016; Zeb, S., \& Sattar, A., 2017; Liao, C. S., 2018).

Agarwal, V., \& Taffler, R. (2008) compared more advanced mathematical approaches such marketbased models such as Black and Scholes (1973) and Merton (1974) models. These theoretical models predict the soundness of banks (Bankruptcy) and have a little forecasting power after controlling other variables compared to Z-score. Noteworthy is the fact that Chiaramonte, L., Croci, E., \& Poli, F. (2015) had examined the validity of Z-score and CAMELS as way of predicting the stability of banks. Similar results were shown for both methodologies. Z-score was regarded as the preferred approach over other 
models, especially CAMELS models, because it required less accounting and questionable data. However, during the financial crisis, the accuracy of the Z-score and CAMELS methods were slightly improved during the whole sample period. The shortcomings of Z-score can be summarized as follows: $Z$-score relies on accounting and auditing structure; banks could smooth out their accounting data over time; the Z-score may give the tendency of the dominance of equity to assets ratio in calculating bank's $Z$-score, the magnitude of the differences in Z-scores may not correspond linearly to the differences in bank risk, since the variation of ROA is only a minor part of the calculation in the numerator (by definition); the calculation of Z-score may be biased upward towards a safer ratio. The limitation of Zscore lies in it's an inability to highlight the forecasting of banks' distance-to-default (Chiaramonte L, Liu H, Poli F, Zhou M., 2016).

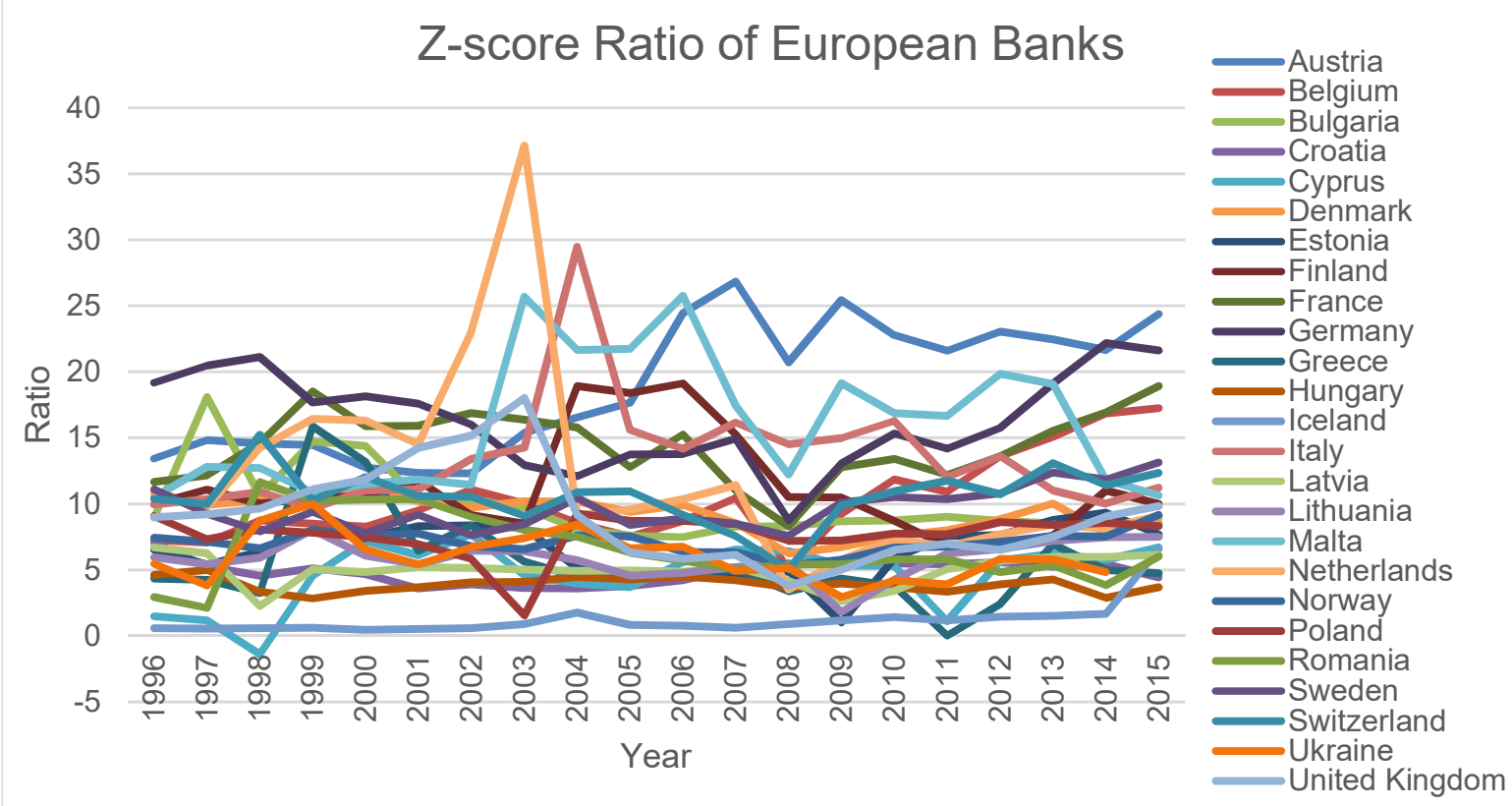

Figure 4. Z-score's Behaviour for European banks for 1996 - 2015

Source: World Bank (citing: Bankscope, Bureau van Dijk (BvD) and Data Market).

The EU-wide stress test is a solvency stress test to assess banks' resilience to shocks with a common adverse macroeconomic scenario and the impact on banks' capital position covers a three-year window. The adverse scenario is a set of systemic risks against the financial stability of the EU banking sector which triggers specific shocks and financial market scenarios, e.g. a severe recession combined with financial market distress. The scenario is unable to capture every possible confluence of events. However, it acts as an analytical tool to understand what happens to banks' balance sheets if an economic downturn occurs, regardless of the specific triggering shock. The effects of common EU scenario are different in different countries, banks' results should be coincided with the relevant scenario.

The key factors included in EU-wide stress test [26] (2018 Eu-Wide Stress Test) was as follows: CET1 capital ratios, leverage ratio, net interest income, credit risk losses, market risk, conduct risk and other operational risk, non-interest income and expenses. The impact on CET1 capital ratios expresses a large dispersion of banks' capital position, both at the starting and at the end-point. CET1 capital ratios vary from $11.6 \%$ to $41.7 \%$ on a transitional basis ( $10.8 \%$ to $41.6 \%$ on a fully loaded basis) at the end of 2017 (non-restated data) and from $7.1 \%$ to $34 \%$ on a transitional basis $(6.4 \%$ to $34 \%$ on a fully loaded basis) by the end of 2020 under the adverse scenario and fully phase-in by the end of 2020 of CRR transitional adjustments that were in force at the beginning of the exercise 2007, such as deferred tax assets (DTAs) that rely on future profitability.

EU Stress Testing showed a large dispersion in the latest report in 2018 where the final CET1 capital ratio was affected by the cumulative decrease of the main sources of banks' income over the adverse scenario compared to the starting point. A reduction in the sources of income led to lower contributions 
to capital compared to the hypothetical contribution of unstressed starting point values. On the other hand, the impact on leverage ratio shows that from 5.4\% in 2017 and expects up to $4.4 \%$ in 2020 under the adverse scenario from $5.1 \%$ to $4.2 \%$ on a fully loaded basis. The drop was solely explained by the decrease in Tier 1 capital as the leverage exposure. In 2017, the minimum actual leverage ratio reported is $3.4 \%$. Under the adverse scenario, two banks reported a ratio below $3 \%$ in 2018 , and three banks both in 2019 and 2020 [27], (2018 Eu-Wide Stress Test).

Table 3. Timeline of Key events in the development of bank stress testing [25], (Dent, K., Westwood, B. Timeline of key events in the development of bank stress testing)



Other macroprudential uses of stress test were to identify early warning exercises of potential weaknesses of the system and enhance crisis management plans (Demirguc-Kunt, Asli, Enrica Detragiache, and Thierry Tressel, 2006; Creel, J., Hubert, P., \& Labondance, F., 2015). Moreover, the impact of hypothetical adverse macroeconomic and financial market scenarios on bank profitability and balance sheets to evaluate the systemic risk and how its relationship to the development of new regulatory and prudential tools. Whereas a macro stress test of credit risk for the banking sector showed strong procyclical behaviors for credit quality and loan quality varies across credit types. Macro stress testing failed to capture the riskier banks in a system and underestimated banks' loan and credit losses. In particular, the macroeconomic module allowed credit volumes to vary over time, while the microeconomic module assumed that individual banks maintained constant credit portfolios. Therefore, the credit quality deteriorated during the downturn of credit growth (Vazquez, Francisco, Benjamin M. Tabak, and Macros Souto, 2012).

\section{The implementation of Basel III and the soundness of European Banking System}

The Basel III Regulation set by the European Bank Authority and the Basel committee were developed in the period spanning two banking crises. Basel III improved the resilience of banks to absorb financial crisis, reduced the risk of system-wide shocks, improved risk management and strengthened the banks' transparency, which can be achieved by setting tighter capital requirements for Minimum Capital. The new requirements of Basel III with respect to regulatory capital for large banks (Important systematic 
banks) were established up as cushion against cyclical changes on their balance sheets. Additionally, capital must set aside for credit expansion which can be loosened during the existence of credit risks.

In addition, Basel III enhanced the microprudential and the macroprudential frameworks. Banks were grouped according to their size and capital requirements could be adjusted based on the size of banks. The Basel III reforms were designed to prevent a recurrence of this kind of banking crisis, through various new mandates: implementation of much stricter capital requirements, new liquidity and leverage testing, and other innovations. The minimum requirements laid down in the Basel framework with regards to the treatment of investments in the capital instruments of insurance company subsidiaries in the definition of the capital and credit risk components were more rigid than the EU requirements. Moreover, the European Union applied a broadly equivalent requirement to raise minimum own funds and eligible liabilities (MREL) to big banks which consisted of a loss absorption amount to cover losses, minimum going-concern capital requirements and a recapitalization amount to meet the conditions for authorization and to maintain market confidence following resolution.

The most significant big banks were subject to a bail-in strategy and the recapitalization amount relatively equal to existing minimum capital requirements. These banks were still able to operate toward a resolution while converting this amount into equity until it was sold or restructured. For small banks, the recapitalization amount would be based on the regulatory capital required to support only the critical economic functions of the bank. The European Banking Authority assumed that small banks were not required to hold any recapitalization amount because they could be subject to liquidation rather than resolution, with eligible depositors being protected through a deposit guarantee scheme. The MREL requirements were based on a bank-by-bank basis concept which created considerable uncertainty over the amount of additional bail-in strategy. However, the regulatory initiatives of Basel III accounted for the risk weighted asset caused by new standardized approaches and constraints on the use of internal models across credit, market and operational risk assessments, and the proposed new capital floor, stress testing, the application of super-equivalent minimum leverage ratios by individual national regulators and macro-prudential policy measurements. For example, Norway and Sweden introduced an application of multiple macro-prudential instruments. As a result, many banks increased capital requirements and overall funding as well as reduced their lending to the wider economy.

Any assessment that recognized the more rigorous implementation of the Basel framework in several respects in different areas was acceptable. Specifically, with respect to the scope of application of the Basel framework, capital buffers and eligibility criteria for recognizing real estate collateral. Meanwhile, it is worth acknowledging that the majority of EU banks were operating according to capital levels set by the Basel committee. However, the aspects of the European Union capital requirements (rules) were not taken into consideration even though they were stronger than the Basel minimum requirements.

The Basel committee also proposed major changes to the requirements for risk exposure weightings by integrating risk exposure weightings capital charges into the capital charges for market risk more broadly and by extending the possibilities to reduce risk exposure weightings requirements through hedging. For instance, banks increased their CET1 capital to maintain their capital ratios to overcome 10 percent in RWAs; or alternatively reduced their RWAs which required huge balance sheet reductions. Due to the uncertainty regarding the Basel Committee's approaches, initiation of the legislative change was difficult to justify without further study.

The Basel III regulations kept banks occupied in a variety of ways and required a great deal of financial resources, manpower, management's decisions, IT-capacity and budgets for external consulting services. Many banks had to quickly raise new equity which required preparation, marketing and execution. Moreover, the new, adjusted and proposed requirements were combined with related regulatory and supervisory initiatives regarding risk data aggregation and reporting, stress tests and recovery and resolution plans. Therefore, the banks options were restricted by Basel III to allocate their equity and funds to particular investments or businesses, and banks needed to adjust their strategies and business models.

The implementation of new rules required three distinct initiatives: strategic planning for the Basel III worldwide, capital and risk strategy, and implementation management. Some of the steps required to 
comply with the new requirements were raising new capital, restructuring the balance sheet and improving profitability to maintain Return on Equity (RoE). Most large systematic banks have established a strategic planning unit to address large parts of this burden. However, in smaller banks, the top management team must focus their attention on these issues as well as their other duties. Alternatively, they could assign at least part of this job to a small, dedicated team of specialists. The high workload caused by the Basel III implementation could limit banks' ability to reduce costs and staff and may depress banks' Return on Equity (RoE).

The national authorities and banks are still in the early stages of the implementation of Basel III and regulatory initiatives, such as the new revised standards on credit, market and operational risk, capital floor, development of revised capital and large exposure standards for sovereign risk exposures. The macro-prudential policy measures and potential regulatory responses to financial technology innovations put extra pressures on banks and affect the transparency of banks performance. Regulation gives the authorities powers to initiate and coordinate the EU-wide stress tests, in cooperation with the European Systemic Risk Board (ESRB) to assess the resilience of financial institutions to adverse market developments, as well as to assess the overall assessment of systemic risk in the EU financial system. The European Banking Authority (EBA) has launched and released 2018 EU-wide stress test and macroeconomic scenarios. The adverse scenario indicates the most severe scenario to date by $8.3 \%$ in 2020 for EU GDP.

Therefore, the uncertainties arising from the unfinished regulatory reforms and reregulation complicate banks' strategic planning and choice of business model. Meanwhile, much of the supervisory pressure coincides with banks' own efforts to improve their profitability, governance, culture and risk management. Supervisory pressure causes much-needed investment and shifts in governance, culture and strategy. For instance, higher Pillar 2 capital may be requested by supervisors to cover risks related to financial technology innovation and/or cyber security. The risk management and compliance challenges related to these developments are also significant. As consequence, the full implement of data, transparency and technology may require years to complete.

It is worth to mentioning that both of Basel I and II were not fully implemented in Europe and Internationally. However, all major banks have met the Basel III minimum CET1 capital, leverage ratio and transitional minimum Liquidity Coverage Ratio of 60 percent, even though some banks stayed below 100 percent minimum and set to be applicable from 2019 (2018 in the EU). Twenty-five percent of banks were below the $100 \%$ minimum Net Stable Funding Ratios (NSFR) that was applied 2018. The leverage ratio is 4.2 percent in Europe where its 5.2 percent internationally; the average NSFR is 104 percent, against 112 percent internationally. In addition, many European banks have experienced a weak economic environment of low or negative growth and low interest rates; low returns on equity; weak net interest margins; a high level of non-performing exposures; high enforcement and remediation costs of misconduct; rising compliance costs; and limited progress on reducing cost to income ratios. If investors start to lose interest in banks, then it will be difficult for them to raise capital. The banks may be forced to enact more rapid measures, such as reduce their balance sheets, restructure and change strategic direction.

\section{Profitability and Bank Soundness}

This section is dedicated to the profitability of banks and the soundness of European banks with focus on the macroeconomic profile. Thus far, this paper details the important role that the macro profile that plays in bank soundness, in comparison, the micro profile gives a year by year estimation of profitability controlled by minimum capital requirements, liquidity and bail-in-able liabilities, but it is unable to determine the soundness of banks for coming years. However, this paper focuses on the macroeconomic scenarios and structural indicators that influence banks' profitability and examines the macroeconomic indicators which have high fluctuations (especially those on the financial markets). The inconsistent trends of profitability have changed the traditional role of banks forcing them to search for new sources of revenue to measure the profitability. Historically, the determinants that influence bank profitability can be categorized in two groups: bank-specific (internal) determinants and industry specific and macroeconomic (external) determinants. 
Most of studies (Goddard, John, Phil Molyneux, and John OS Wilson, 2004; Molyneux, Philip, and John Thornton, 1992; Pasiouras, Fotios, and Kyriaki Kosmidou, 2007; Athanasoglou, Panayiotis P., Sophocles N. Brissimis, and Matthaios D. Delis, 2008; Petria, Nicolae, Bogdan Capraru, and Iulian Ihnatov, 2015) have examined the profitability of European banks. However, bank profitability determinants could have been used to predict financial crises (Demirgüç-Kunt, A., \& Detragiache, E, 2005; Kibritçioglu, Aykut, 2003; Demirgüç-Kunt, A., \& Detragiache, E., 2000; Albertazzi, U., \& Gambacorta, L, 2009 and others). Most of the empirical findings were consistent with the expected results that factors, such as credit and liquidity risk, management efficiency, the diversification of business, the market concentration, competition and the economic growth have an influence on bank profitability, both on RoA and RoE (Combey, A., \& Togbenou, A., 2017). However, some studies suggested that despite high competition there were signs of abnormal profit from year to year.

\section{Determinants of Bank Profitability}

This paper is centered on bank determinants and their impact on profitability, while all previous literature that dealt with the determinants of bank profitability focused on the returns on assets (ROA) and returns on equity (ROE). Another key determinant is capital adequacy ratio which measures the banks' financial health entity and capital bank strength. Moreover, higher capital ratio means low external funding and higher profit (Bourke 1989; Kosmidou, 2008). Banks with higher capital are more protected from insolvency problems and risk exposure. Better capitalized banks reduce the funding cost, risk and protect banks from insolvent, efficient management of banks' expenses and liquidity management contribute to higher banks' profitability (Abreu and Mendes, 2001; Pasiouras, F., \& Kosmidou, K., 2007; Ally, Z, 2014; Ozili, P. K., 2015; Menicucci, E., \& Paolucci, G., 2016). Moreover, there exists a significantly negative correlation between poor asset quality (high non-performing loans to total asset) and return on equity. Loans generate the major share of banks income; therefore, the quality of loan portfolio reflects on the profitability of banks. The capital structure depends heavily on debt financing rather than equity financing; thus, a higher cost of debt financing decreases bank performance (Ongore, V. O., \& Kusa, G. B., 2013).

Any financial strength and risks in a bank's assets are measured by asset quality ratio that associated with the loans and investments. A comprehensive evaluation of asset quality is very crucial to measure the current and the future status of banks' viability (Demirguc-Kunt, 1989). In the banking sector, the quality of assets depends on many factors such as exposure to specific risks, non-performing loans trends, and at the same time, banks borrowers' profitability and health. Typically, failure of any bank was due to poor asset quality and low levels of liquidity. The higher the level of non-performing loans, the lower the profitability which was caused by risk-taking behavior of banks management and weak performance (Athanasios Tsagkanos, and Athanasios Bellas, 2014; Ongore, V. O., \& Kusa, G. B., 2013). The asset quality ratio is associated with number of bank-specific and macroeconomic factors that employed a powerful influence on the rates of non-performing loans. Determinants such as size, efficiency, credit growth, and real GDP growth and market power are significant because they can cause risky loans and bad debts (V Makri, A Tsagkanos, A Bellas, 2014; Messai, F Jouini, 2013).

Higher real interest rates cause an immediate increase in debt and non-performing loans due to floating rates (Messai, F Jouini, 2013). Liquidity risk means banks are more vulnerable to large deposit withdrawals caused by holding fewer liquid assets. There was a negative relationship between liquidity ratio and profitability (Molyneux \& G 1992; Kosmidou, 2008; Guru, B. K., Staunton, J., \& Balashanmugam, B., 2002). Some empirical evidence on banks' profitability summarized that a positive significant link between bank liquidity and profitability (Bourke, 1989). However, during downturn, banks are in favor of increasing their cash holding to mitigate risk. Higher figures of liquidity ratios for domestic banks indicated a negative relationship between bank profitability and liquidity (Pasiouras, F., \& Kosmidou, K., 2007). However, foreign banks showed lower figures of liquidity ratios which indicated a positive relationship between liquidity and profitability.

Another liquidity indicator is deposit ratio which is measured by the ratio of total deposits to total assets, even though it may be considered as a liability. Customer deposits have a positive impact on profitability since they allow banks to transform deposits liabilities into income earning assets, which reflect positively on banks performance and operating efficiency. It is expected that higher upward deposits 
improve bank activities and more profits (Lee and Hsieh, 2013). However, more customer deposits may reduce earnings since the demands on loans are few and less profitable (Menicucci, E., \& Paolucci, G., 2016).

Management efficiency measures the performance of management through subjective evaluation of management quality, organizational discipline, control systems, quality of staff, and other factors. Since bank management makes crucial decisions that could lead to risk perception, investors and financial analysts use the finance ratio to evaluate management efficiency. The administrative expenses to total assets ratio indicate a lack of competence in expense management and has a negative impact on profitability (Athanasoglou, P. P., Brissimis, S. N., \& Delis, M. D., 2008; Rani, D. S., \& Zergaw, L. N., 2017). Moreover, (Ongore, V. O., \& Kusa, G. B., 2013) suggested that poor asset quality or high nonperforming loans to total asset was associated with poor bank performance. Furthermore, (Staikouras, C. K., \& Wood, G. E., 2011) also mentioned that banks with greater levels of equity or banks with large non-loan earning assets were more profitable than banks that relied heavily on assets.

The cost-to-income ratio measures the impact of efficiency on banks profitability. Therefore, a higher level of cost-income ratios means lower profit and margin (Kosmidou, K., Tanna, S. and Pasiouras, F., 2005; Kosmidou, K., 2008; Altunbas, Y., Carbo, S., Gardener, E. P., \& Molyneux, P., 2007). It was typically used as an indicator of management's ability to control costs. This ratio evaluates the productivity and efficiency in banks, while also comparing productivity and efficiency of banks. When the cost to income ratio is high, the lower the productivity, also the lower the efficiency (Burger, Andreas, et al., 2008; Athanasoglou, P. P., Brissimis, S. N., \& Delis, M. D., 2008).

Loan loss provisions are shown in their profit and used to predict the estimated loss in their loan portfolio(s) before the actual loss occurred. Especially during upturns, the loan-loss reserves should result in direct charges against earnings and anticipate future losses on the loan portfolio during economic downturn. When banks' anticipated loan losses were due, banks relied on these reserves to absorb the losses without going after other resources such as capital and will be less exposed to the credit risk. The ratio of loan loss provisions is inversely related to banks' return on assets (Staikouras, C. K., \& Wood, G. E., 2004). However, Altunbas, Y., Carbo, S., Gardener, E. P., \& Molyneux, P. (2007) showed that the level of loan loss provisions is negatively correlated for commercial bank and efficient banks' capital levels within a country, but has a positive influence for savings and cooperative banks.

The level of loan loss provisioning reflects on the bank's management vision on the quality of their loan portfolio to cover the whole spectrum of anticipated credit losses, while at the same time considers this provision as a credit risk measurement. Also, the loan loss provisions over total loans proxies the credit quality and capital risk in banks. A higher level of this ratio and a lower credit quality has a negative impact on profitability. When banks operate in risky environments and are unable to control banks' lending operations, they could afford higher loan-loss provision ratio to cover this risk (U1 Mustafa, A. R., Ansari, R. H., \& Younis, M. U., 2012).

There are huge differences in earnings performance among banks, and there are several factors that could cause variability of bank profits, such as size of banks, ownership, structure and the quality of bank management in selected countries, asset portfolios and liabilities composition. Thus, earnings quality can be reflected in the quality of a bank's profitability and its' steady earning.

The following charts represent the behavior of some of internal factors of profitability for European banks from 2007-2017: 


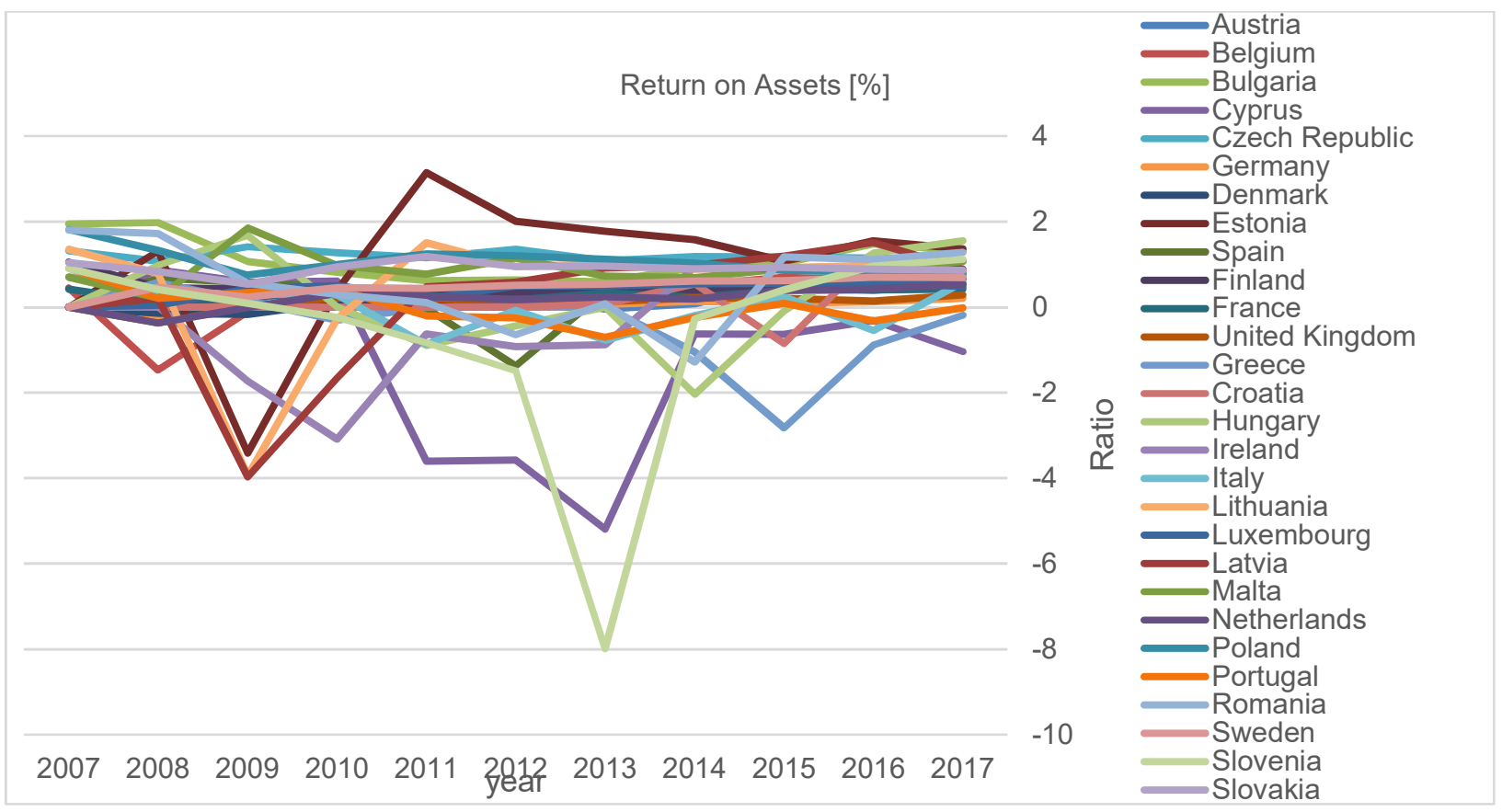

Figure 5. Return on Assets for European banks from 2007-2017: Data Resource. European Central Bank- Consolidated Banking data [28] (All banking groups / stand-alone banks irrespective of their accounting / supervisory reporting framework)

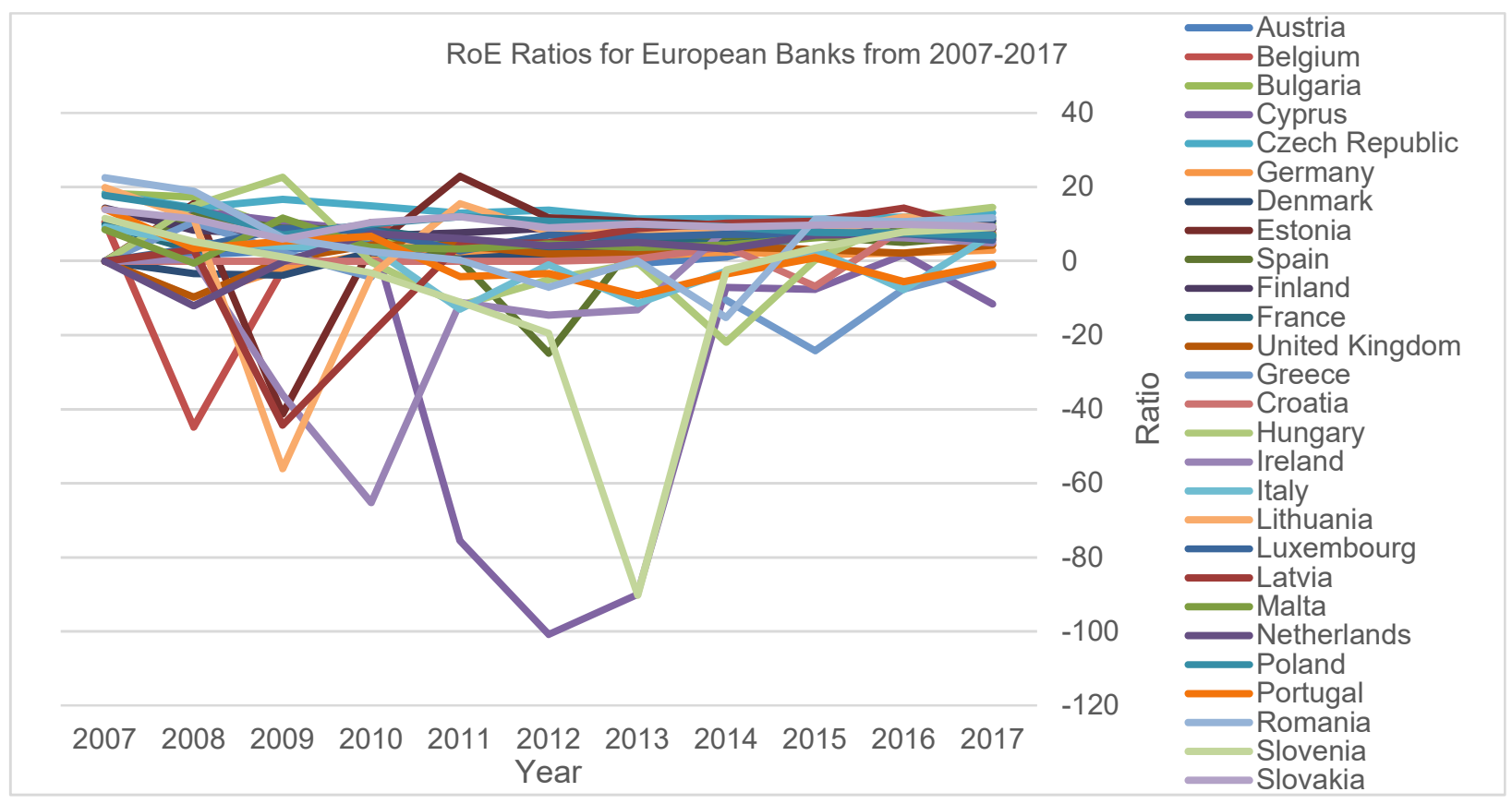

Figure 6: Return on Equity European banks from 2007-2017: Data Resource. European Central Bank- Consolidated Banking data [29] (All banking groups / stand-alone banks irrespective of their accounting / supervisory reporting framework) 


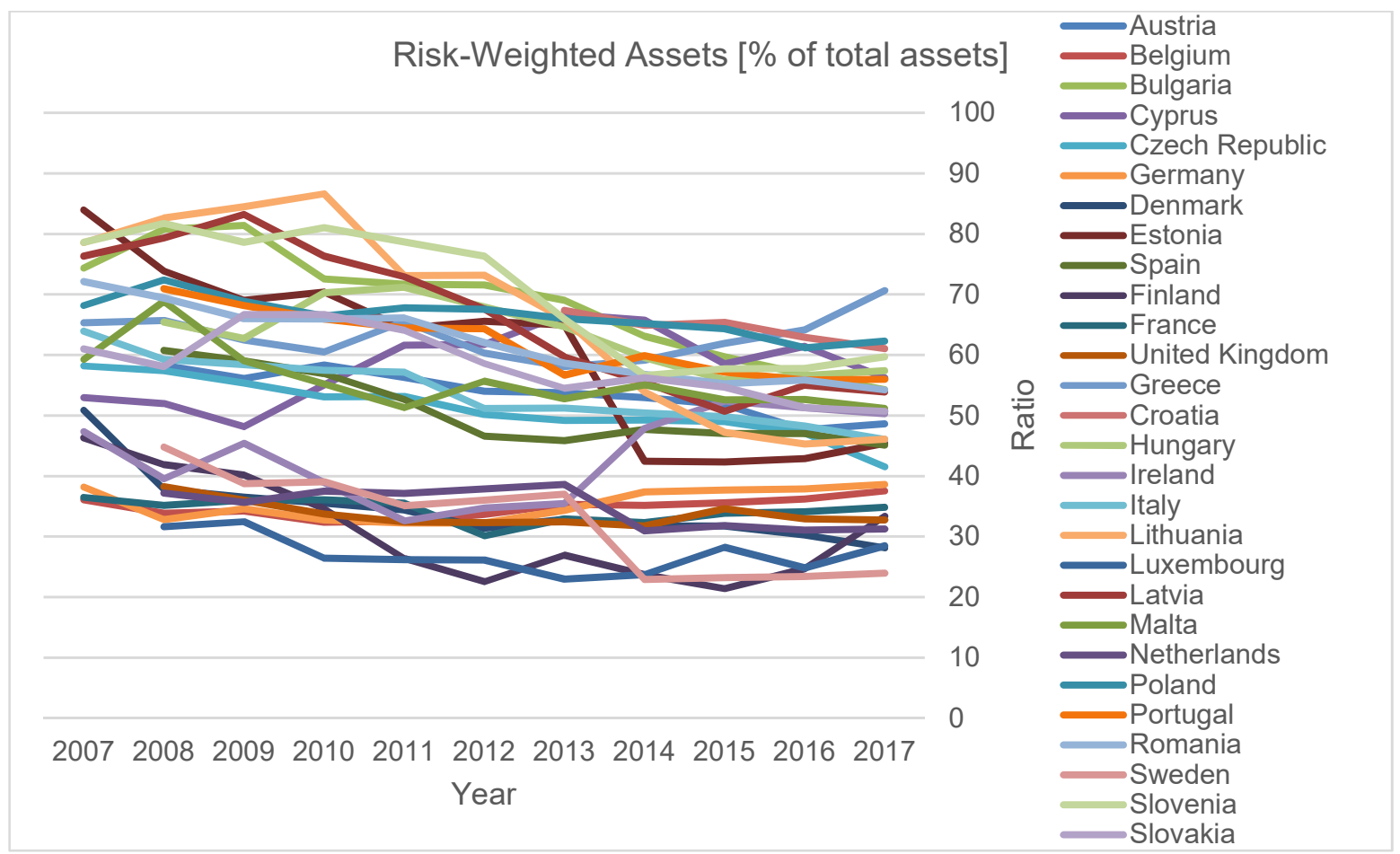

Figure 7: Risk-Weighted Assets Ratios: Data resource. European Central Bank- Consolidated Banking Data [30] (All banking groups / stand-alone banks irrespective of their accounting / supervisory reporting framework)

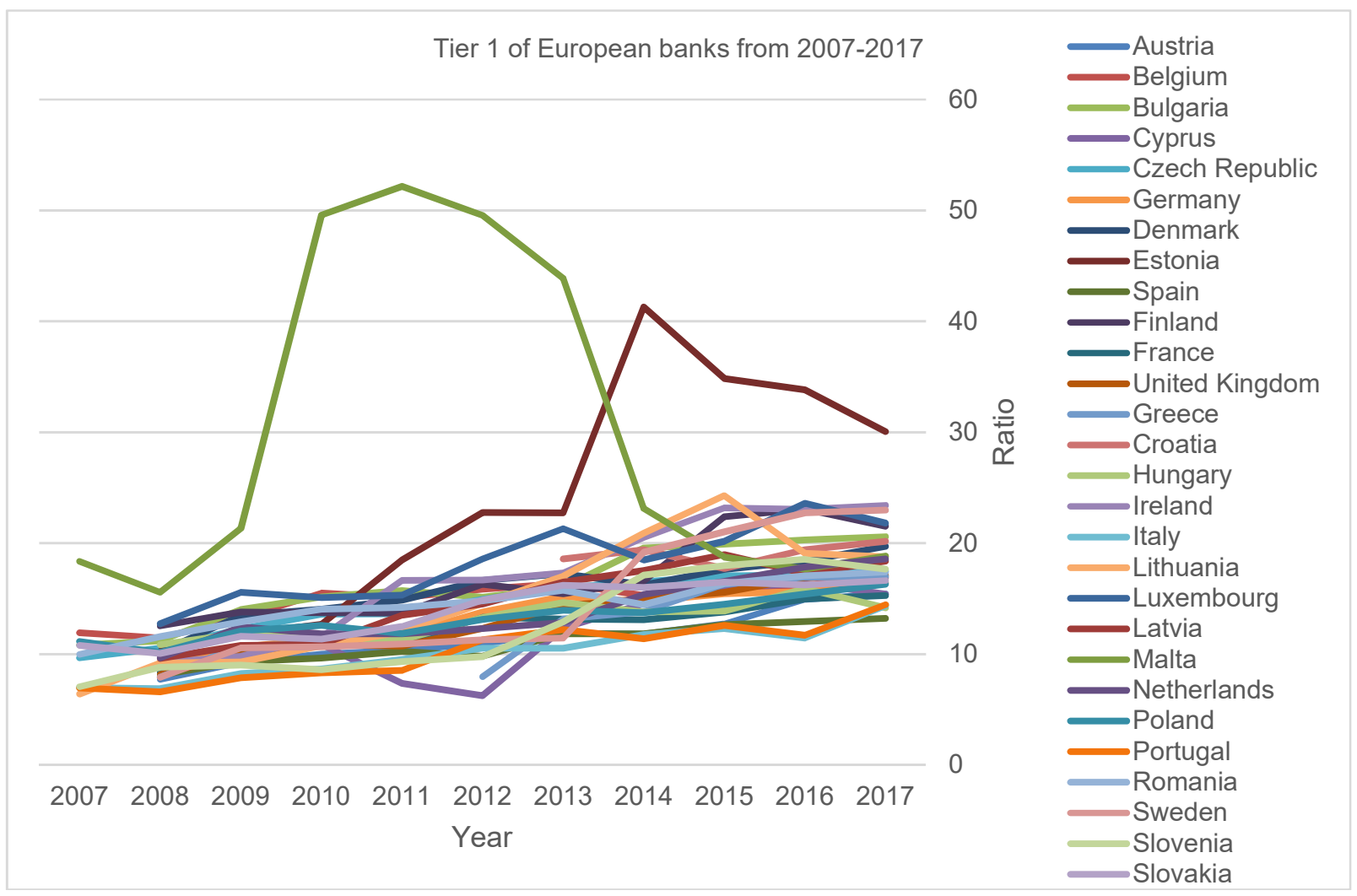

Figure 8: Tier 1 of European Banks from 2007-2017. Data Resource-European Central Bank- Consolidated Banking data. 


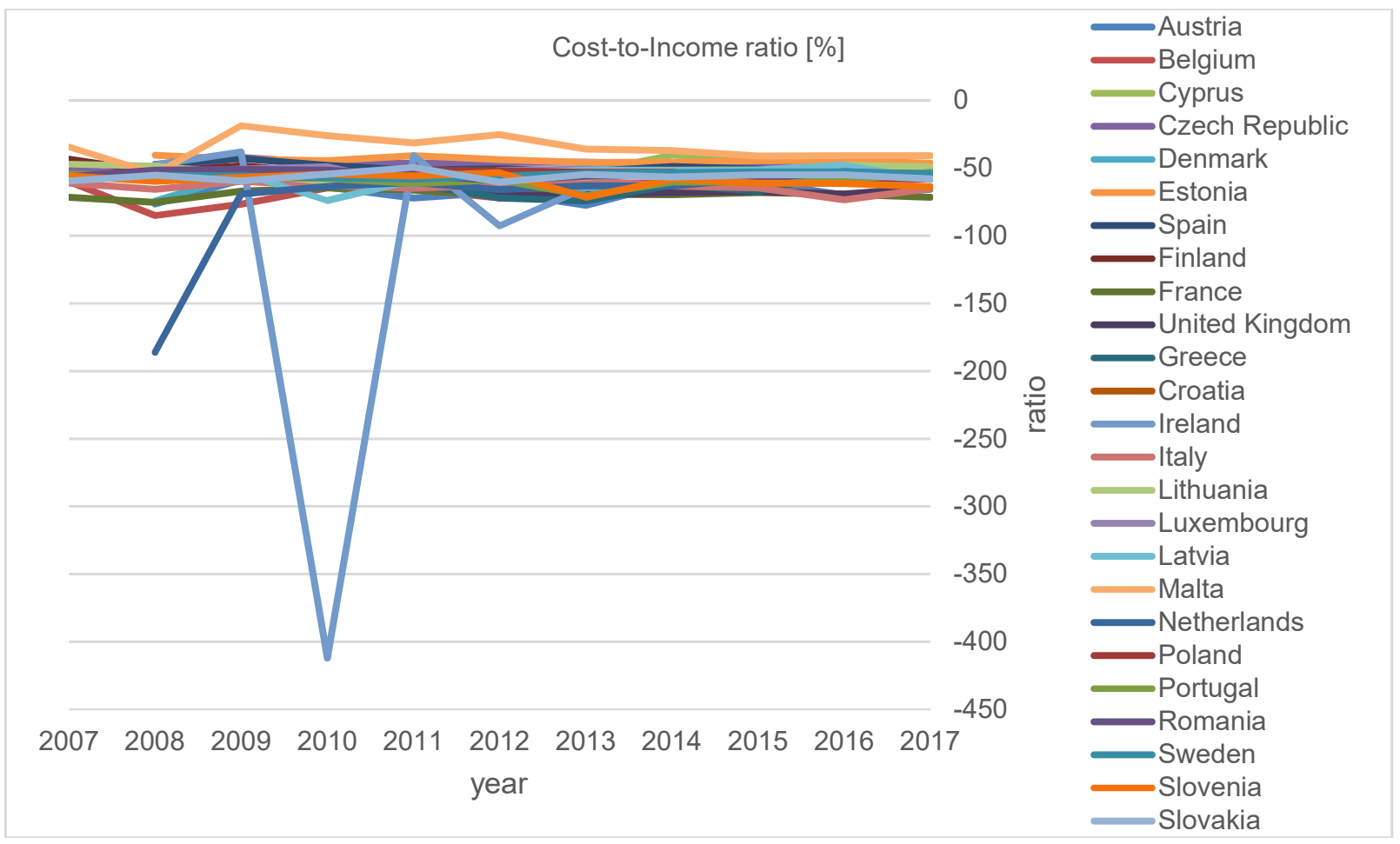

Figure 9: Cost-to- Income Ratio for European Banks from 2007-2018. Data Resource- European Central Bank- Consolidated Banking data [31] (All banking groups / stand-alone banks irrespective of their accounting / supervisory reporting framework)

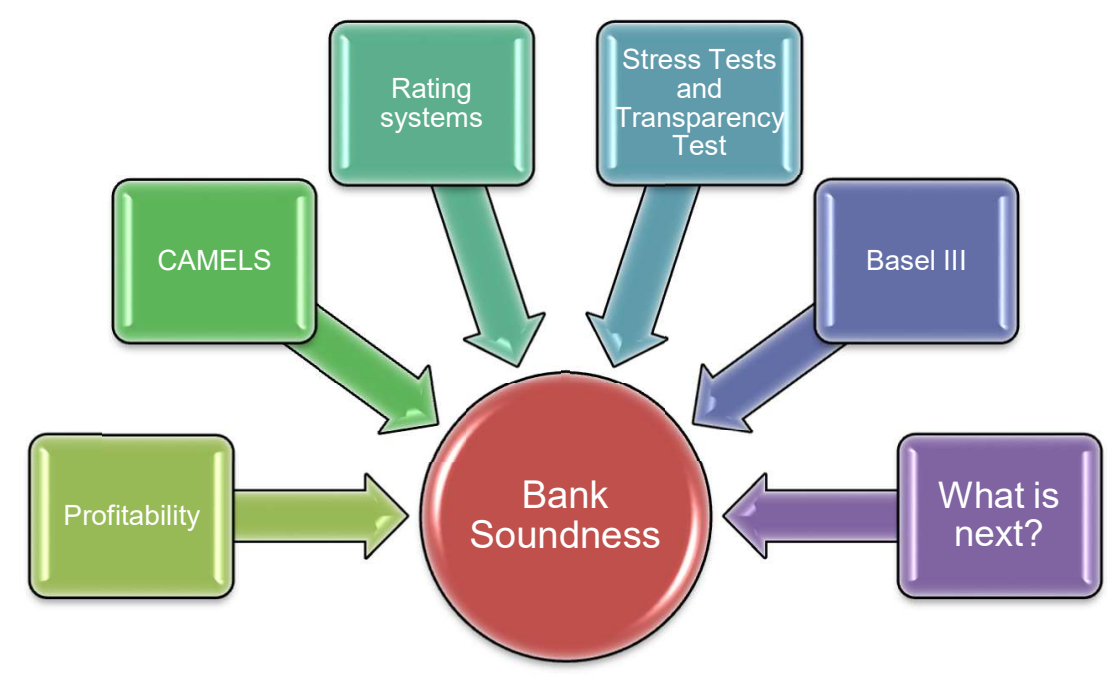

Figure 10: the most used methodologies to examine the bank soundnes 


\section{The Topology of Soundness of Banks:}

Starting with the casual dynamic model used by Bastan M., Mazrae, M. B., \& Ahmadvand, A. (2016) for CAMEL model, I expanded their approach to include the selected methodologies to examine all possible factors and sub-factors that influence the soundness banks from the qualitative analysis point view. I used a different dynamic system model, then noticed that the following causal diagram of the structure of soundness of banks became very complex. Therefore, I analyzed separately a number of the key causal trees to understand each part of the structure of the soundness of banks. This model can be used as explanatory map to describe the topology of soundness of banks.



Figure 11. The Casual Diagram of Soundness of banks based on the methodologies are Mentioned in this Study

The first causal tree is related to the soundness of banks which provides a clear image about the possible structure of soundness of banks with a connection to the selected methodologies. Figure 12 shows the main and sub-factors of selected methodologies that affect the soundness of banks. Many factors could be added to make this model, or combined more methodologies to make the structure of soundness of banks more accurate in the future. 


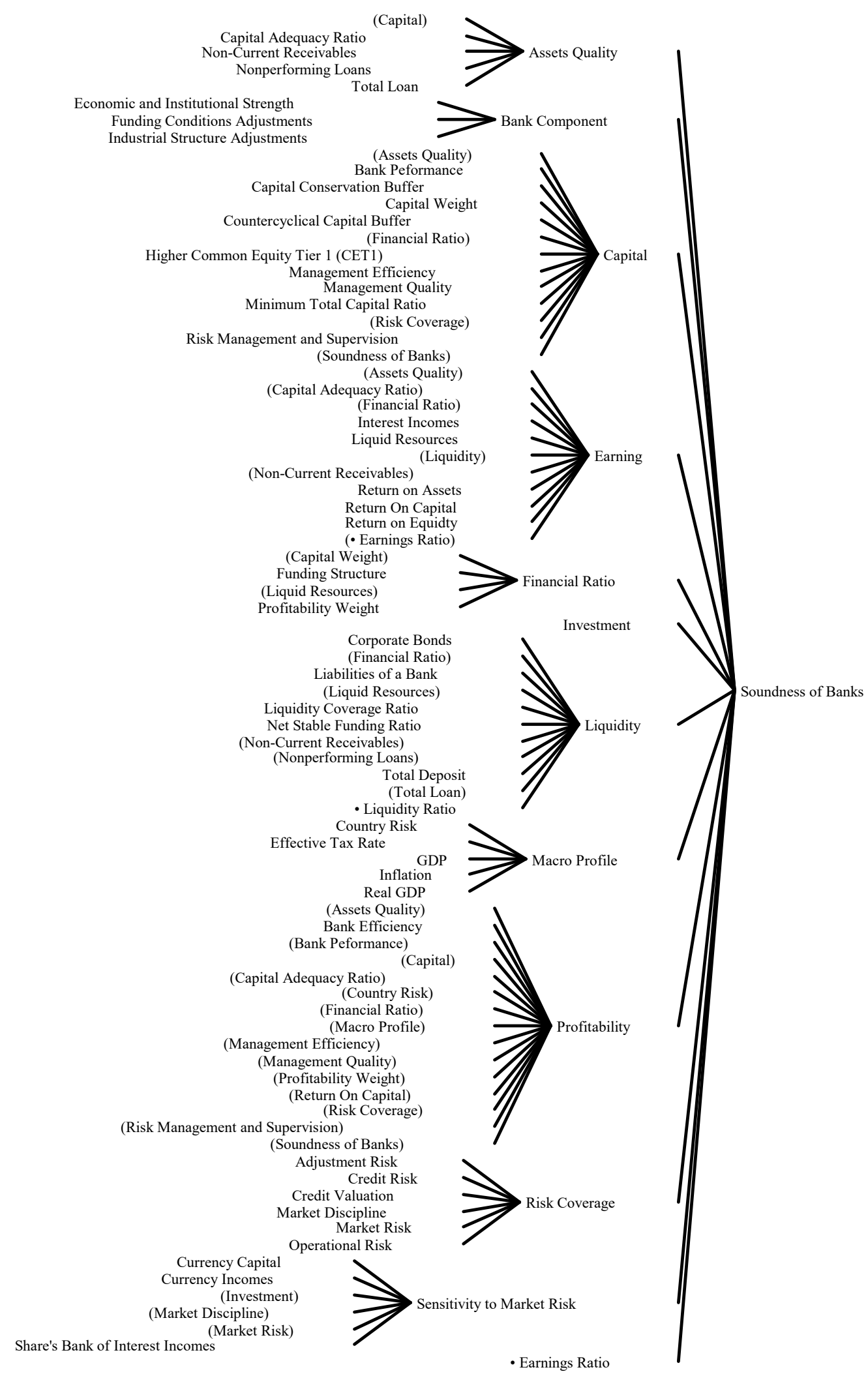

Figure 12: Casual Tree of Soundness of Banks 
Figure 13 shows the causal tree of profitability, and it demonstrates that profitability is primarily affected by assets quality, bank performance, macro profile and regulatory and supervisory role of the soundness of banks.

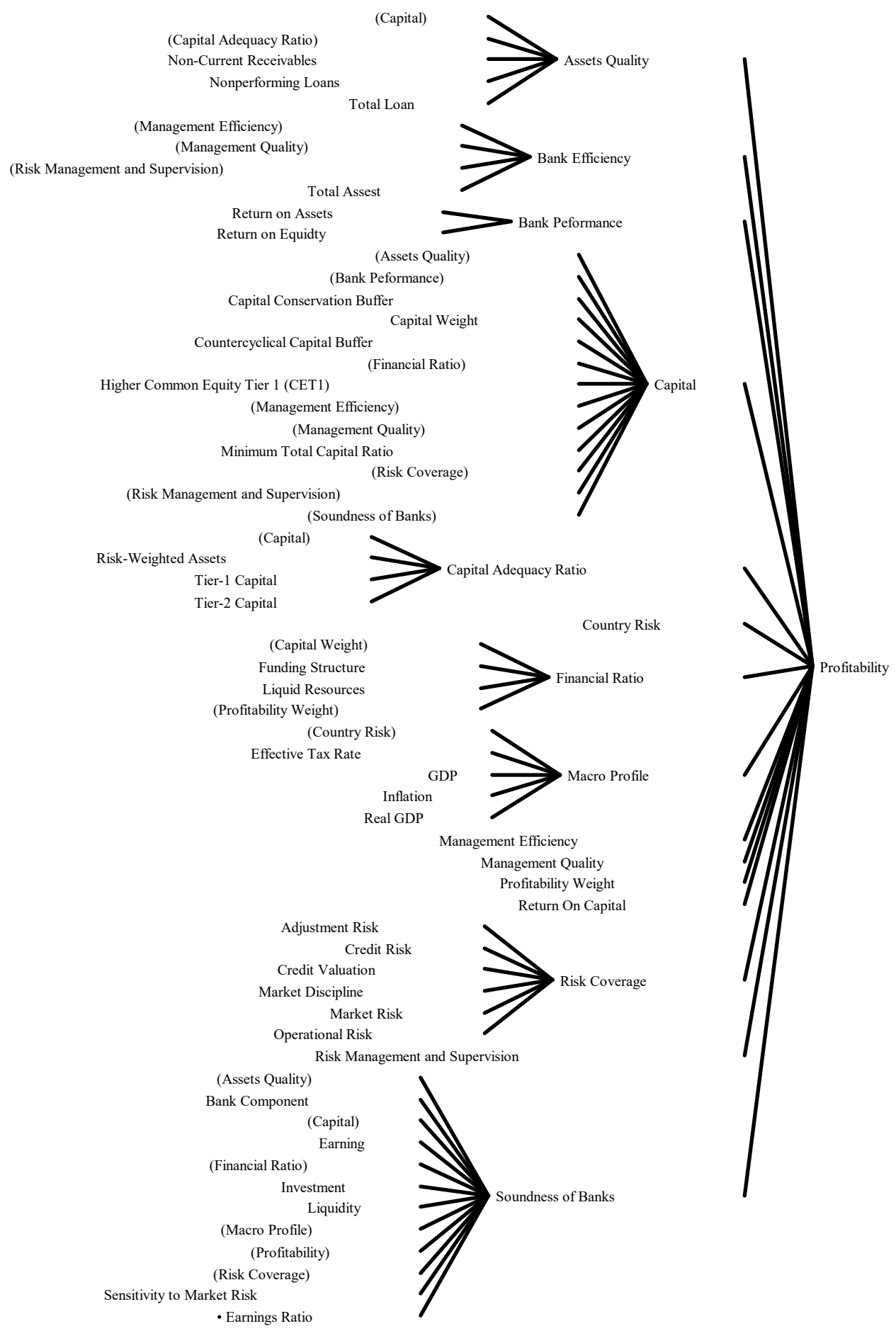

Figure 13: Casual Tree of Profitability 
ISSN (online) - 2521-1242 ISSN (print) - 2521-1250

Figures 14 and 15 show the impact of other components on the soundness of a bank. Regarding capital, the outcome focuses mainly on the Basel III requirements.

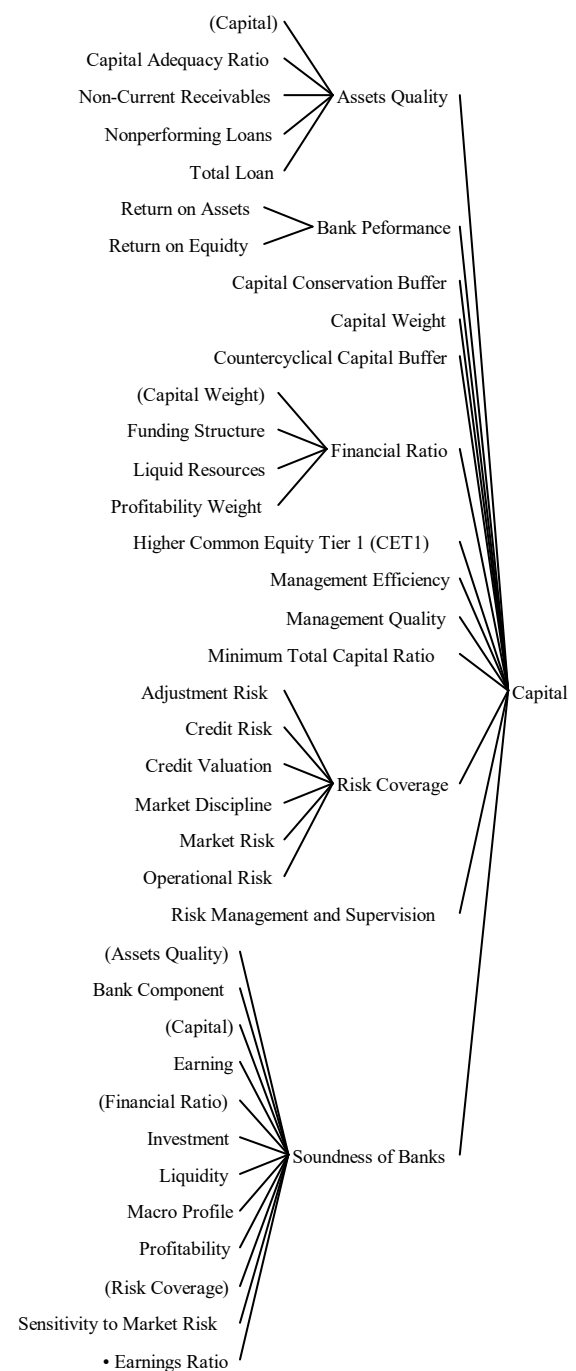

Figure 14: Casual Tree of Bank's Capital and Earning

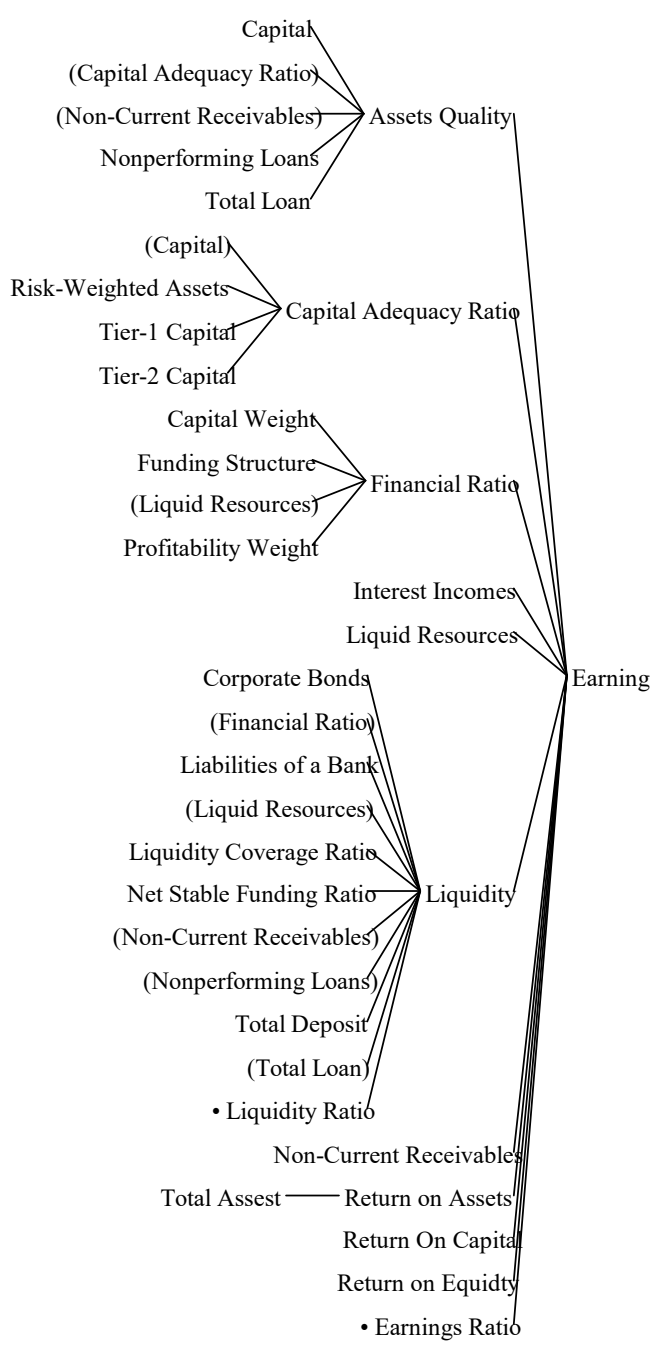

Figure 15: Casual Tree Earning

The outcomes of this research are:

Table 3. The paper results and outcome

\begin{tabular}{|c|c|c|c|}
\hline & Research question & Results & Reasons \\
\hline 1. & $\begin{array}{l}\text { Examine the similarities and dif- } \\
\text { ferences between the most re- } \\
\text { peated methodologies to examine } \\
\text { the soundness of European banks } \\
\text { and profitability. }\end{array}$ & $\begin{array}{l}\text { The similarities between the } \\
\text { methodologies are more than } \\
\text { the differences among them. }\end{array}$ & $\begin{array}{l}\text { Most of Methodologies rely on both the Micro and the } \\
\text { Macro profiles to examine the soundness of banking } \\
\text { systems. However, methodologies, such as CAMEL } \\
\text { and Z-score have become less effective to examine the } \\
\text { soundness of banks. However, they could be used to } \\
\text { give a quick outlook on the bank's soundness. }\end{array}$ \\
\hline 2. & $\begin{array}{l}\text { Is there a methodology that depicts } \\
\text { the linkages between profitability, } \\
\text { market structure, performance and } \\
\text { the soundness of banks? }\end{array}$ & Indeterminate & $\begin{array}{l}\text { The combination of the regression model and other } \\
\text { methodologies, such as rating systems or Z-score bank- } \\
\text { ing rating for each country as well as taking in consid- } \\
\text { eration the macro profile gives more accurate image on } \\
\text { the soundness of banks. }\end{array}$ \\
\hline 3. & $\begin{array}{l}\text { Are new regulations, methodolo- } \\
\text { gies or supervisory measurements } \\
\text { needed to determine European } \\
\text { Banks soundness? }\end{array}$ & Indeterminate & $\begin{array}{l}\text { Any new methodology has to be built on existing meth- } \\
\text { odologies with modifications to fit the new require- } \\
\text { ments and regulatory climate. }\end{array}$ \\
\hline
\end{tabular}




\section{Conclusion}

All of the methodologies that have been addressed in this study show that the bank soundness is built exclusively on internal, bank industry and external determinants of the banks' profitability. Measuring bank soundness through Z-scores yields similar results to the CAMEL or CAMELS methods; however, both of these approaches are less effective without including the macro profile. Moreover, these two approaches are less effective during crises. This paper asserts that other qualitative factors, such as banks' history and management ethics will also have an effect on bank soundness and have not been included in empirical studies. To my knowledge, reliance only on capital adequacy; assets; management; earnings and liquidity can be very effective to evaluate banks soundness on the micro level. However, the shortcomings of the CAMEL or CAMELS approaches are highlighted when the external factors are excluded in many empirical studies; the evaluation of bank stability becomes ineffective in the long run. It was noted that the Moody's structure for forecasting banks' failures and credit profiles accurately employed the macro profile qualitative approach. When external factors were added to the Z-score and CAMEL methodologies, the bank soundness predictions were generally improved, even though the change was deemed insignificant in some studies.

The methodologies which have been used in the most of empirical studies were repeated with similar results. The old methodologies were outdated, but by adding supervision regulations and regulatory, they became more effective to predict the soundness of banks. This paper emphasized the current trend to divide banks into two categories: good banks and bad banks. As part of my future investigations, I will use new approaches, such as discrimination analysis and survival analysis that isolated the bad banks. As far as the Basel III and supervisory institutes, the lack of clarity of the new regulations shows their over complexity and interdependence. Many of the new measures are interdependent directly or indirectly due to the structure of the balance sheet, bank's investment and funding decisions. Therefore, it will be difficult to prepare for the Basel III regulations in time and in an integrated manner. In other words, the new regulatory measures call for new or adjusted calculations, which lead to new requirements on data mining, data analysis, linking of data and quality of data. These new requirements will require IT-implementation and testing, of data aggregation and reporting, development of internal models and risk management improvement to reflect less risk-sensitive regulatory approaches. Even though European banks have maintained strong capital position in recent years, some dispersion remains among institutions and in the EU. Most EU banks have successfully implemented the Basel III advanced approaches for capital requirements led by the most internationally active banks.

Finally, in this paper, a dynamic system model represents the structure of banking soundness with a qualitative analysis approach using Vensim Software. This model graphically depicts the 42 key components of bank soundness each with its own loop. It offers an examination of all possible factors that influence the soundness banks from the qualitative analysis point view. It should be noted that the structure of bank soundness casual diagram in this study did not conclude all of the variables used in the selected methodologies, therefore a great deal of further investigation was required.

\section{References: -}

1. Abreu, M., \& Mendes, V. (2001, May). Commercial bank interest margins and profitability: Evidence for Some EU Countries. In Pan-European Conference Jointly Organized by the IEFS-UK \& University of Macedonia Economic \& Social Sciences, Thessaloniki, Greece,17-20.

2. Agarwal, V., \& Taffler, R. (2008). Comparing the performance of market-based and accounting-based bankruptcy prediction models. Journal of Banking \& Finance, 32(8), 1541-1551, doi:10.1016/j.jbankfin.2007.07.014.

3. Albertazzi, U., \& Gambacorta, L. (2009). Bank Profitability and the Business Cycle. Journal of Financial Stability, 5(4), 393-409, doi: 10.1016/j.jfs.2008.10.002.

4. Ally, Z. (2014). Determinants of banks' profitability in a developing economy: Empirical evidence from Tanzania. European Journal of Business and Management, 6(31), 363-375.

5. Assets.kpmg. (2016). [online] Available at: https://assets.kpmg/content/dam/kpmg/pdf/2016/07/capitalmyths-realtities.pdf. Accessed 9 Dec. 2018.

6. Athanasoglou, P. P., Brissimis, S. N., \& Delis, M. D. (2008). Bank-Specific, Industry-Specific and Macroeconomic Determinants of Bank Profitability. Journal of international financial Markets, Institutions and Money, 18(2), 121-136, doi: 10.1016/j.intfin.2006.07.001.

7. Athanasoglou, P., Delis, M., \& Staikouras, C. (2006). Determinants of Bank Profitability in the South Eastern European Region. Online at https://mpra.ub.uni-muenchen.de/10274/, 1-31. 
Financial Markets, Institutions and Risks, Volume 3, Issue 2, 2019 ISSN (online) - 2521-1242 ISSN (print) - 2521-1250

8. Altunbas, Y., Carbo, S., Gardener, E. P., \& Molyneux, P. (2007). Examining the relationships between capital, risk and efficiency in European banking. European Financial Management, 13(1), 49-70, doi:10.1111/j.1468-036x.2006.00285.x.

9. Baral, K. J. (2005). Health Check-Up of Commercial Banks in the Framework of CAMEL: A case Study of Joint Venture Banks in Nepal. Journal of Nepalese Business Studies, 2(1), 41-55, doi:10.3126/jnbs.v2i1.55.

10. Barth, J. R., Dopico, L. G., Nolle, D. E., \& Wilcox, J. A. (2002). Bank Safety and Soundness and the Structure of Bank Supervision: a Cross-country Analysis. International Review of Finance, 3(3-4), 163-188, doi:10.1111/j.1369-412x.2002.00037.x.

11. Abbasi, E., Bastan, M., \& Ahmadvand, A. M. (2016). A system dynamics model for mobile banking adoption. 2016 12th International Conference on Industrial Engineering (ICIE). doi:10.1109/induseng.2016.7519341.

12. Burger, A., \& Moormann, J. (2008). Productivity in banks: myths \& truths of the cost income ratio. Banks and Bank Systems, Volume 3, Issue 4, 85-94.

13. Bustamam, U. S. A. (2017). CAMEL Ratio on Profitability Banking Performance (Malaysia Versus Indonesia). International Journal of Management, Innovation \& Entrepreneurial Research, 3(1), 30-39, doi:10.18510/ijmier.2017.314.

14. Boyd, J. H., \& Runkle, D. E. (1993). Size and Performance of Banking Firms: Testing the predictions of theory. Journal of monetary economics, 31(1), 47-67, doi: 10.1016/0304-3932(93)90016-9.

15. Bourke, P. (1989). Concentration and other determinants of bank profitability in Europe, North America and Australia. Journal of Banking \& Finance, 13(1), 65-79, doi:10.1016/0378-4266(89)90020-4.

16. Chen, S., \& Holdings, C. F Altman, E. I., Heine, M. L., Zhang, L., \& Yen, J. (2007). Corporate financial distress diagnosis in China. Salomon Center Working Paper, New York University.

17. Chiaramonte, L., Croci, E., \& Poli, F. (2015). Should We Trust the Z-score? Evidence from the European Banking Industry. Global Finance Journal, 28, 111-131, doi: 10.1016/j.gfj.2015.02.002.

18. Chiaramonte, L., Liu, H., Poli, F., \& Zhou, M. (2016). How Accurately Can Z-score Predict Bank Failure?. Financial Markets, Institutions \& Instruments, 25(5), 333-360, doi: 10.1111/fmii.12077.

19. Combey, A., \& Togbenou, A. (2017). The Bank Sector Performance and Macroeconomics Environment: Empirical Evidence in Togo. International Journal of Economics and Finance, 9(2), 180. doi:10.5539/ijef.v9n2p180.

20. Čihák, M., \& Hesse, H. (2010). Islamic Banks and Financial Stability: An Empirical Analysis. Journa of Financial Services Research, 38(2-3), 95-113, doi:10.1007/s10693-010-0089-0.

21. Creel, J., Hubert, P., \& Labondance, F. (2015). Financial Stability and Economic Performance. Economic Modelling, 48, 25-40, doi:10.2139/ssrn.2495405.

22. Curak, Marijana, Klime Poposki, and Sandra Pepur (2012). "Profitability determinants of the Macedonian banking sector in changing environment." Procedia-Social and Behavioral Sciences 44 (2012): 406-416, doi: 10.1016/j.sbspro.2012.05.045.

23. Dang, U. (2011), The CAMEL Rating System in Banking Supervision: A Case Study. Arcada University of Applied Sciences. International Business, p 1-47.

24. Davydenko, A. (2010). Determinants of Bank Profitability in Ukraine. Undergraduate Economic Review, 7(1), 2, 1-31. Available at: http://digitalcommons.iwu.edu/uer/vol7/iss1/2.

25. Demirgüç-Kunt, A. (1989). Modeling large commercial-bank failures: a simultaneous-equation analysis. Federal Reserve Bank of Cleveland, Research Department, doi: 10.26509/frbc-wp-198905.

26. Demirgüç-Kunt, A., \& Detragiache, E. (2000). Monitoring Banking Sector Fragility: a Multivariate Logit Approach. The World Bank Economic Review, 14(2), 287-307, doi: 10.5089/9781451856712.001.

27. Demirgüç-Kunt, A., \& Detragiache, E. (2011). Basel Core Principles and Bank Soundness: Does Compliance Matter?. Journal of Financial Stability, 7(4), 179-190, doi:10.1016/j.jfs.2010.03.003.

28. Demirgüç-Kunt, A., \& Detragiache, M. E. (2010). Basel Core Principles and Bank Risk: Does Compliance Matter? (No. 10-81). International Monetary Fund, doi: 10.5089/9781451982671.001.

29. Demirgüç-Kunt, A., \& Huizinga, H. (1999). Determinants of Commercial Bank Interest Margins and Profitability: Some International Evidence. The World Bank Economic Review, 13(2), 379-408, doi:10.1093/wber/13.2.379.

30. Demirgüç-Kunt, A., \& Huizinga, H. (2000). Financial Structure and Bank Profitability. World Bank Policy Research Working Paper, (2430), 1-30.

31. Demirguc-Kunt, A., \& Levine, R. (2008). Finance, Financial Sector Policies, and Long-Run Growth. The World Bank., doi: 10.1596/1813-9450-4469. 
Financial Markets, Institutions and Risks, Volume 3, Issue 2, 2019

ISSN (online) - 2521-1242 ISSN (print) - 2521-1250

32. Demirguc-Kunt, A., Detragiache, E., \& Tressel, T. (2006). Banking on The Principles: Compliance with Basel Core Principles and Bank Soundness. Policy Research Working Papers. doi:10.1596/1813-9450-3954.

33. Demyanyk, Y., \& Hasan, I. (2010). Financial crises and bank failures: A review of prediction methods. Omega, 38(5), 315-324. doi: 10.1016/j.omega.2009.09.007.

34. Dent, K., Westwood, B., \& Segoviano Basurto, M. (2016). Stress testing of banks: an introduction. Bank of England Quarterly Bulletin, Q3.

35. Dincer, H., Gencer, G., Orhan, N., \& Sahinbas, K. (2011). A Performance Evaluation of the Turkish Banking Sector after the Global Crisis via CAMELS Ratios. Procedia-Social and BehavioralSciences, 24, 1530-1545. doi: 10.1016/j.sbspro.2011.09.051.

36. Eba.europa.eu. (2019). Results - European Banking Authority. [online] Available at: https://eba.europa.eu/documents/10180/2419200/2018-EU-wide-stress-test-Results.pdf. Accessed 9 Jan. 2019.

37. European Central Bank, https://www.ecb.europa.eu/pub/pdf/annex/ecb.fcdb20170731.en.xlsx.Accessed 21, August 2018.

38. FDIC RMS Manual of Examination Policies (2019). [online] Available at: https://www.fdic.gov/ regulations/safety/manual/section7-1.pdf. Accessed 9 Jan. 2019.

39. Gasbarro, D., Sadguna, I. G. M., \& Zumwalt, J. K. (2002). The Changing Relationship between CAMEL Ratings and Bank Soundness during the Indonesian Banking Crisis. Review of Quantitative Finance and Accounting, 19(3), 247-260, doi:10.1023/a:1020724907031.

40. Goddard, J., Molyneux, P., \& Wilson, J. O. (2004). The Profitability of European banks: a Cross Sectional and Dynamic Panel Analysis. The Manchester School, 72(3), 363-381, doi:10.1111/j.14679957.2004.00397.x.

41. Gambacorta, L. (2008). How do Banks Set Interest Rates?. European Economic Review, 52(5), 792-819, doi:10.1016/j.euroecorev.2007.06.022.

42. Guru, B. K., Staunton, J., \& Balashanmugam, B. (2002). Determinants of commercial bank profitability in Malaysia. Journal of Money, Credit, and Banking, 17(1), 69-82.

43. Hays, F. H., De Lurgio, S. A., \& Gilbert, A. H. (2009). Efficiency Ratios and Community Bank Performance. Journal of Finance and Accountancy, 1(1), 1-15.

44. Ishaq AB, Karim A, Ahmed S, Zaheer A (2016). Evaluating Performance of Commercial Banks in Pakistan: “An Application of Camel Model”. J Bus Fin Aff 5: 169, doi:10.4172/2167-0234.1000169.

45. Kumar, M. A., Harsha, G. S., Anand, S., \& Dhruva, N. R. (2012). Analyzing Soundness in Indian Banking: A CAMEL approach. Research Journal of Management Sciences, Vol. 1(3), 9-14.

46. Kaur, H. V. (2010). Analysis of Banks in India-A CAMEL Approach. Global Business Review, 11(2), 257-280, doi:10.1177/097215091001100209.

47. Kibritçioglu, A. (2003). Monitoring Banking Sector Fragility. The Arab Bank Review, 5(2), 51-66.

48. Kosmidou, K. (2008). The Determinants of Banks' Profits in Greece during the Period of EU Financial Integration. Managerial finance, 34(3), 146-159, doi: 10.1108/03074350810848036.

49. Kosmidou, K., Tanna, S., \& Pasiouras, F. (2005, June). Determinants of Profitability of Domestic UK Commercial Banks: Panel Evidence from the Period 1995-2002. In Money Macro and Finance (MMF) Research Group Conference, 45,1-27.

50. Laeven, L., \& Levine, R. (2009). Bank Governance, Regulation and Risk Taking. Journal of Financial Economics, 93(2), 259-275, doi: 10.3386/w14113.

51. Lapteacru, I. (2016). On the Consistency of the Z-score to Measure the Bank Risk. SSRN Electronic Journal, doi:10.2139/ssm.2787567.

52. Lapteacru, I. (2017). The Z-score is Dead, Long Live the Z-score! A New Way to Measure Bank Risk, SSRN Electronic Journal, doi:10.2139/ssrn.2963525.

53. Lee, C. C., \& Hsieh, M. F. (2013). The impact of bank capital on profitability and risk in Asian banking. Journal of international money and finance, 32, 251-281, doi:10.1016/j.jimonfin.2012.04.013.

54. Liao, C. S. (2018). Risk-taking and Efficiency of Banks for Emerging Eastern Asian Countries. Advances in Management and Applied Economics, 8(5), 11-25.

55. Manoj, P. K. (2010). Financial Soundness of Old Private Sector Banks (OPBs) in India and Benchmarking the Kerala Based OPBs: a 'CAMEL' Approach. American Journal of Scientific Research, 11, 132-149.

56. Makri, V., Tsagkanos, A., \& Bellas, A. (2014). Determinants of non-performing loans: The case of Eurozone. Panoeconomicus, 61(2), 193-206, doi:10.2298/PAN1402193M.

57. Menicucci, E., \& Paolucci, G. (2016). Factors affecting bank profitability in Europe: An empirical investigation. African Journal of Business Management, 10(17), 410-420, doi:10.5897/ajbm2016.8081. 
Financial Markets, Institutions and Risks, Volume 3, Issue 2, 2019

ISSN (online) - 2521-1242 ISSN (print) - 2521-1250

58. Messai, A. S., \& Jouini, F. (2013). Micro and macro determinants of non-performing loans. International journal of economics and financial issues, 3(4), 852-860.

59. Messai, A.S., \& JOUINI, F. (2013). Predicting Banking Distress in European Countries. Journal of Economic and Social Studies, 3(1), 61-83, doi:10.14706/jecoss11312.

60. Miller, M. H. (1998). The current Southeast Asia Financial Crisis. Pacific-Basin Finance Journal, 6(3-4), 225-233, doi:1016/S0927-538x(98)00009-2.

61. Mirzaei, A., Moore, T., \& Liu, G. (2013). Does Market Structure Matter on Banks' Profitability and Stability? Emerging vs. Advanced Economies. Journal of Banking \& Finance, 37(8), 2920-2937, doi: 10.1016/j.jbankfin.2013.04.031.

62. Molyneux, P., \& Forbes, W. (1995). Market structure and performance in European banking. Applied Economics, 27(2), 155-159, doi:10.1080/00036849500000018.

63. Molyneux, P., \& Thornton, J. (1992). Determinants of European bank Profitability: A note. Journal of Banking \& Finance, 16(6), 1173-1178, doi:10.1016/0378-4266(92)90065-8.

64. Muhmad, S. N., \& Hashim, H. A. (2015). Using the Camel Framework in Assessing Bank Performance in Malaysia. International Journal of Economics, Management and Accounting, 23(1) 109-127. Retrieved from https://journals.iium.edu.my/enmjournal/index.php/enmj/article/view/292.

65. Ongore, V. O., \& Kusa, G. B. (2013). Determinants of financial performance of commercial banks in Kenya. International journal of economics and financial issues, 3(1), 237-252.

66. Ozili, P. K. (2015). Loan Loss Provisioning, Income Smoothing, Signaling, Capital Management and Procyclicality: Does IFRS Matter? Empirical Evidence from Nigeria. Mediterranean Journal of Social Sciences, doi:10.5901/mjss.2015.v6n2p224.

67. Ozili, P. K. (2015). How Bank Managers Anticipate Non-Performing Loans Evidence from Europe, US, Asia and Africa. Applied Finance and Accounting, 1(2), 73-80, doi:10.11114/afa.v1i2.880.

68. Pasiouras, F., \& Kosmidou, K. (2007). Factors influencing the profitability of domestic and foreign commercial banks in the European Union. Research in International Business and Finance, 21(2), 222-237, doi: 10.1016/j.ribaf.2006.03.007.

69. Petria, N., Capraru, B., \& Ihnatov, I. (2015). Determinants of Banks’ Profitability: Evidence from EU 27 Banking systems. Procedia Economics and Finance, 20, 518-524, doi: 10.1016/S2212-5671(15)00104-5.

70. Rani, D. S., \& Zergaw, L. N. (2017). Bank specific, industry specific and macroeconomic determinants of bank profitability in Ethiopia. International Journal of Advanced Research in Management and Social Sciences, 6(3), 74-96.

71. Roman, A., \& Şargu, A. C. (2013). Analysing the Financial Soundness of the Commercial Banks in Romania: An Approach based on the Camels Framework. Procedia Economics and Finance, 6, 703-712, doi: 10.1016/s2212-5671(13)00192-5

72. Sangmi, M. U. D., \& Nazir, T. (2010). Analyzing Financial Performance of Commercial Banks in India: Application of CAMEL model. Pakistan Journal of Commerce and Social Sciences (PJCSS), 4(1), 40-55.

73. Staikouras, C. K., \& Wood, G. E. (2004). The Determinants of European Bank Profitability. International Business and Economics Research Journal, 3, 57-68.

74. Schaeck, K., \& Cihák, M. (2008). How Does Competition Affect Efficiency and Soundness in Banking? New Perspectives and Empirical Evidence. SSRN Electronic Journal. doi:10.2139/ssrn.1088605

75. Schaeck, K., \& Cihák, M. (2014). Competition, Efficiency, and Stability in Banking. Financial Management, 43(1), 215-241, doi:10.1111/fima.12010.

76. Takang, F. A., \& Ntui, C. T. (2008). Bank performance and credit risk management.

77. Zeb, S., \& A. (2017). Financial Regulations, Profit Efficiency, and Financial Soundness: Empirical Evidence from Commercial Banks of Pakistan. The Pakistan Development Review, 56(2), 85-103, doi: 10.30541/v56i2pp.85-103.

78. Uhde, A., \& Heimeshoff, U. (2009). Consolidation in Banking and Financial Stability in Europe: Empirical Evidence. Journal of Banking \& Finance, 33(7), 1299-1311, doi: 10.1016/j.jbankfin.2009.01.006.

79. Ul Mustafa, A. R., Ansari, R. H., \& Younis, M. U. (2012). Does the Loan Loss Provision Affect the Banking Profitability in Case of Pakistan? Asian Economic and Financial Review, 2(7), 772-783.

80. Vazquez, F., Tabak, B. M., \& Souto, M. (2012). A Macro Stress Test Model of Credit Risk for the Brazilian Banking Sector. Journal of Financial Stability, 8(2), 69-83, doi: 10.1016/j.jfs.2011.05.002.

\section{Online resourses}

1. Retrieved from https://www.moodys.com/researchdocumentcontentpage.aspx?docid=PBC 79004 
2. A Loss Given Failure (LGF) assesses the impact of the bank's failure on the expected loss of each creditor (see https://www.moodys.com/microsites/brm/SP29913 AnalyticalApproach.pdf?WT.z referringsource=BRM Overview).

3. https://www.moodys.com/microsites/brm/SP29913 AnalyticalApproach.pdf?WT.z referringsource $=$ BRM Overview

4. $\quad$ https://www.moodys.com/microsites/brm/SP29913_AnalyticalApproach.pdf?WT.z_referringsource=BRM Overview

5. $\quad$ https://www.moodys.com/login?ReturnUrl=https://www.moodys.com/research/Moodys-German-Banking-System-Outlook-remains-stable-on-strong-capital--PR 390236

6. $\quad$ https://www.moodys.com/research/Moodys-changes-outlook-for-Austrias-banking-system-to-stable-from--PR_388007

7. $\quad$ https://www.moodys.com/research/Moodys-French-banking-system-outlook-remains-stable-as-revenue-diversification-PR 391311

8. $\quad$ https://www.moodys.com/research/Moodys-raises-outlook-for-Spanish-banking-system-to-positive-as--PR 385047

9. $\quad$ https://www.moodys.com/research/Moodys-says-Outlook-on-UK-banking-system-remains-stable-on--PR 389662

10. https://www.moodys.com/research/Moodys-keeps-Polands-Banking-System-Outlook-at-stable-on-strong--PR 389483

11. https://www.moodys.com/research/Moodys-Outlook-for-Czech-banking-system-raised-to-positive-on--PR 392304

12. https://www.moodys.com/research/Moodys-Bulgarian-banks-performance-will-be-supported-by-rising-profits-PR 370094

13. $\quad$ https://www.moodys.com/research/Moodys-Upgrades-Bulgarian-Banks-Deposit-Ratings--PR 368622

14. https://www.moodys.com/research/Moodys-Dutch-banking-system-outlook-kept-at-stable-as-asset--PR 392246

15. https://www.moodys.com/research/Moodys-Greek-banking-system-outlook-changed-to-positive-on-improving-PR 387198

16. $\quad$ https://www.moodys.com/research/Moodys-takes-rating-actions-on-Greek-banks--PR 379602

17. https://www.moodys.com/research/Moodys-Outlook-for-Italian-banking-system-remains-negative-on-higher--PR 392274

18. https://www.moodys.com/research/Moodys-takes-action-on-12-Italian-financial-institutions--PR 390365

19. https://www.moodys.com/research/Moodys-Outlook-on-Irish-banking-system-changed-to-positive-as--PR_389938

20. https://www.moodys.com/research/Moodys-upgrades-Bank-of-Cyprus-and-Hellenic-Banks-deposit-ratings--PR 394014

21. $\quad$ https://www.moodys.com/research/Moodys-Robust-economic-recovery-supports-positive-outlook-on-Cypriot-banking-PR 380768

22. https://www.moodys.com/research/Moodys-changes-outlook-on-Norwegian-banks-to-stable-from-negative--PR 388068

23. https://en.wikipedia.org/wiki/CAMELS rating system

24. $\quad$ see $h$ ttps://www.bis.org/publ/bcbs130.htm

25. $\quad$ https://pdfs.semanticscholar.org/5d09/f79085b9130b1915ac9ab88cd4b0c42b37cd.pdf and https://eba.europa.eu/documents/10180/2419200/2018-EU-wide-stress-test-Results.pdf

26.

27.

28.

29.

30.

31. https://eba.europa.eu/documents/10180/2419200/2018-EU-wide-stress-test-Results.pdf (see https://eba.europa.eu/documents/10180/2419200/2018-EU-wide-stress-test-Results.pdf)

Full sample (All banking groups / stand-alone banks irrespective of their accounting / supervisory reporting framework)

Full sample (All banking groups / stand-alone banks irrespective of their accounting / supervisory reporting framework)

Full sample (All banking groups / standalone banks irrespective of their accounting / supervisory reporting framework) Full sample (All banking groups / standalone banks irrespective of their accounting / supervisory rporting framework) 